\title{
B Cell Responses in the Development of Mammalian Meat Allergy
}

\author{
Jessica L. Chandrasekhar ${ }^{1 \dagger}$, Kelly M. Cox $^{2 \dagger}$ and Loren D. Erickson ${ }^{1,2 *}$ \\ ${ }^{1}$ Beirne B. Carter Center for Immunology Research, University of Virginia School of Medicine, Charlottesville, VA, \\ United States, ${ }^{2}$ Department of Microbiology, Immunology, and Cancer Biology, University of Virginia School of Medicine, \\ Charlottesville, VA, United States
}

OPEN ACCESS

Edited by:

Shiv Pillai,

Harvard Medical School,

United States

Reviewed by:

Jose De La Fuente

Institute of Game and Wildlife

Research (CSIC), Spain

Alejandro Cabezas-Cruz,

Institut National de Recherche pour

l'agriculture, l'alimentation et

l'environnement (INRAE), France

*Correspondence:

Loren D. Erickson

loren@virginia.edu

tThese authors have contributed equally to this work

Specialty section: This article was submitted to B Cell Biology,

a section of the journal

Frontiers in Immunology

Received: 05 May 2020

Accepted: 10 June 2020

Published: 17 July 2020

Citation:

Chandrasekhar JL, Cox KM and Erickson LD (2020) B Cell Responses

in the Development of Mammalian Meat Allergy.

Front. Immunol. 11:1532 doi: 10.3389/fimmu.2020.01532
Studies of meat allergic patients have shown that eating meat poses a serious acute health risk that can induce severe cutaneous, gastrointestinal, and respiratory reactions. Allergic reactions in affected individuals following meat consumption are mediated predominantly by IgE antibodies specific for galactose- $\alpha$-1,3-galactose ( $\alpha$-gal), a blood group antigen of non-primate mammals and therefore present in dietary meat. $\alpha$-gal is also found within certain tick species and tick bites are strongly linked to meat allergy. Thus, it is thought that exposure to tick bites promotes cutaneous sensitization to tick antigens such as $\alpha$-gal, leading to the development of lgE-mediated meat allergy. The underlying immune mechanisms by which skin exposure to ticks leads to the production of $\alpha$-gal-specific IgE are poorly understood and are key to identifying novel treatments for this disease. In this review, we summarize the evidence of cutaneous exposure to tick bites and the development of mammalian meat allergy. We then provide recent insights into the role of B cells in IgE production in human patients with mammalian meat allergy and in a novel mouse model of meat allergy. Finally, we discuss existing data more generally focused on tick-mediated immunomodulation, and highlight possible mechanisms for how cutaneous exposure to tick bites might affect $B$ cell responses in the skin and gut that contribute to loss of oral tolerance.

Keywords: adaptive immune response, B cells, allergy, meat, IgE, ticks

\section{INTRODUCTION}

Mammalian meat allergy, also known as $\alpha$-gal syndrome, is among a minority of food allergies that pose a serious acute health risk that induces cutaneous, gastrointestinal, and respiratory reactions in patients after eating non-primate mammalian meat such as beef, pork, or lamb $(1,2)$. This novel form of food allergy develops worldwide in adults who have tolerated meat consumption for years and is mediated predominantly by IgE antibodies specific for the carbohydrate galactose- $\alpha-1,3$-galactose ( $\alpha$-gal) that is expressed on cells and tissues of dietary meat (1-11). Allergic reactions in patients range from mild to severe hives, itchiness, nausea, vomiting, and abdominal pain $3-6 \mathrm{~h}$ after eating meat $(1,12,13)$. Moreover, some patients progress to anaphylaxis after consuming meat, though the reasons for this severe reaction in a subset of patients are unknown. Individuals with $\alpha$-gal-specific IgE have also reported severe allergic reactions to drugs derived from mammalian cells and tissue that contain $\alpha$-gal residues $(10,14,15)$.

The development of mammalian meat allergy has been linked to tick bites. In the United States, bites from Amblyomma americanum (lone star tick) are associated with meat allergy (3). A. americanum has been considered a tick species inhabiting the southern and southeastern states. 
However, the range of $A$. americanum has expanded northward into the northern Mid-western states, north central states, and northeastern Atlantic states as far north as Maine (16-18). One hypothesis for this expansion is that the hosts for lone star ticks, such as white-tailed deer, are increasing in population and migrating northward due to climatic and environmental changes $(17,19)$. Based on these studies, along with case reports of IgE-mediated anaphylactic reactions to meat cropping up in areas outside the south, it is projected that mammalian meat allergy associated with lone star ticks will increase in future years. Multiple case reports have been further published describing the association between $\alpha$-gal IgE and meat allergy in Central America (1, 3, 4), Europe (5-7), Australia (2, 20), Asia (8, 9), and South Africa (21). Ticks are endemic in all of these regions yet vary in species. This raises the notion that tick species linked to meat allergy share immune modulating factors that trigger $\alpha$-gal sensitization.

Unlike other tick-borne diseases caused by viral and bacterial infections that may be prevented by vaccination or antibiotics, there is no treatment to prevent or cure meat allergy. Further efforts are needed to understand the immune mechanisms by which cutaneous exposure to ticks leads to sensitization and the production of pathogenic IgE antibodies. Such efforts would solidify tick bites as the cause of meat allergy and identify new, more specific targets for the treatment and prevention of this food allergy. Here, we review recent progress in studies of the immune reactions in mammalian meat allergy. A particular emphasis is devoted to $\mathrm{B}$ cell responses given the important association of $\alpha$-gal IgE to meat allergy and IgE-mediated drug reactions. We also discuss the features of the $\alpha$-gal carbohydrate allergen and tick-host interactions that might provide insights into the immune mechanisms that lead to cutaneous sensitization.

\section{MAMMALIAN MEAT ALLERGY}

Allergic reactions against $\alpha$-gal were first recognized in the United States in 2006 following the FDA approval of cetuximab, a mouse-human chimeric mAb to Epidermal Growth Factor Receptor, for the treatment of advanced bowel and head and neck cancer (22). Clinical trials of cetuximab indicated a low risk of hypersensitivity responses and when reactions in patients did occur they were mild $(22,23)$. However, as the number of cancer patients being treated with cetuximab increased, a high frequency of hypersensitivity reactions was observed in patients located in the southeastern United States. Studies conducted at the University of North Carolina revealed that severe (grade 3 or 4 ) reactions occurred in $\sim 22 \%$ of cancer patients treated with cetuximab, far higher than the frequency of $3 \%$ observed nationally (14). Analysis of pre-treatment serum revealed that the individuals who experienced hypersensitivity reactions had pre-existing IgE that bound to cetuximab. Further work determined that these IgE antibodies were specific to $\alpha$ gal, a carbohydrate found on the murine portion of cetuximab (10). Numerous case reports of healthy individuals experiencing urticaria, angioedema, or anaphylaxis with no clear cause also came to the attention of physicians during this time (1). These cases occurred in the same southeastern region of the US as the severe hypersensitivity reactions in cancer patients treated with cetuximab. Some individuals indicated that the hypersensitivity responses occurred several hours after consuming red meat, such as beef, pork, lamb, or venison. In many cases, the individuals who experienced these hypersensitivity responses had a history of consuming meat for decades with no adverse reaction (12). Intradermal testing with beef, pork and lamb extracts elicited strong positive results, and oral food challenges ultimately confirmed that eating red meat caused the delayed hypersensitivity responses (1). Further work revealed that $\alpha$-galspecific IgE contributed significantly to the allergic response to red meat in these individuals (1). For a more detailed overview of the clinical diagnosis and risk factors for mammalian meat allergy, we refer the readers to two recent reviews $(24,25)$.

Both cetuximab-induced hypersensitivity and meat allergy cases were restricted to the same geographical area, mainly North Carolina, Virginia, Tennessee, Arkansas, and part of Missouri (14). Three individuals investigating the $\alpha$-gal syndrome story developed meat allergy and all had been recently bitten by lone star ticks (3). Comparison of serum obtained before and after tick bites in these individuals revealed a significant increase in $\alpha$-gal-specific IgE titers following tick bites, suggesting that tick bites could drive the production of $\alpha$-gal-specific IgE antibodies. Further investigation revealed that a large number of patients in the US with meat allergy also had a history of lone star tick bites. Analysis of serum from these meat allergic patients revealed a significant correlation between $\operatorname{IgE}$ to $\alpha$-gal and IgE to A. americanum proteins $(3,26)$, which declines over time in patients who avoid tick bites (27). The total number of annual meat allergy cases in the United States has been estimated to be 5,000 (28). Meat allergy cases associated with $\alpha$ gal-specific IgE antibodies have also been reported in Australia (2), Brazil (29), France (7, 30, 31), Germany (6), Spain (9), Sweden $(5,32)$, and Japan (33). Interestingly, subjects with type 1 sensitization to $\alpha$-gal that clearly tolerate meat consumption have been identified in screening tests $(34,35)$. Recently, the basophil activation test (BAT) has been shown to distinguish patients with mammalian meat allergy from asymptomatic $\alpha$ gal-sensitized subjects (36). Why these subjects are asymptomatic after eating meat is unclear but might signify individuals at risk of developing meat allergy.

\section{GALACTOSE- $\alpha-1,3-$ GALACTOSE}

Studies of the biochemical nature and function of $\alpha$-gal first began more than two decades ago in the xenotransplantation field, as a major target for human anti-pig antibodies is the $\alpha$ gal epitope expressed on pig organs (37-41). The $\alpha$-gal epitope is a carbohydrate synthesized on membrane-bound and secreted glycolipids and glycoproteins by the glycosylation enzyme $\alpha$ 1,3-galactosyltransferase (GT) (42). GT catalyzes the last step of $\alpha$-gal biosynthesis by attaching galactose to the $\mathrm{N}$-Acetyl$D$-lactosamine. $\alpha$-gal is expressed on cells of all non-primate mammals below Old World monkeys, whereas Old World 
monkeys, apes and humans lack the GT enzyme and thus do not synthesize $\alpha$-gal epitopes and produce $\alpha$-gal-specific antibodies $(43,44)$. All healthy humans naturally produce IgM and IgG antibodies to $\alpha$-gal beginning in infancy (45), and it is these pre-existing antibodies to $\alpha$-gal that drive the acute rejection of porcine xenografts (46-49). This production of $\alpha$ gal-specific antibodies is thought to be driven by the continuous exposure of B cells to $\alpha$-gal expressed by microorganisms that colonize the gastrointestinal tract $(45,50,51)$. $\alpha$-gal has been found in a variety of bacteria of the human flora, including Escherichia coli, Klebsiella, and Salmonella strains isolated from human stool and blood, with some strains expressing $\alpha$-gal on the carbohydrate portion of bacterial lipopolysaccharides $(45,52)$. Furthermore, several human pathogens express $\alpha$-gal. These include some that are not tick-borne pathogens, such as Plasmodium spp. (53), Trypanosoma cruzi (54), Leishmania spp. $(55,56)$, Mycobacterium marinum $(57,58)$, Aspergillus fumigatus (59), and Schistosoma mansoni (59), as well as others that are tick-borne pathogens, such as Anaplasma phagocytophilum and Borrelia spp. (60). These findings support the hypothesis that bacteria of normal flora may provide chronic $\alpha$-gal exposure to B cells for the production of $\alpha$-gal-specific IgM and IgG antibodies to protect the host against pathogens that express $\alpha$-gal.

Interestingly, $\alpha$-gal epitopes have been detected in the gut (32), saliva (29), salivary gland (33), ovaries (61), and cement (62) of several tick species linked to meat allergy. One possibility for the source of this $\alpha$-gal is residual glycoproteins containing $\alpha$ gal from a blood meal of non-primate hosts, as $\alpha$-gal epitopes increase over time in the salivary glands of lone star ticks after blood feeding $(63,64)$. An alternative explanation is that ticks are able to produce endogenous $\alpha$-gal. BLAST searches of the putative genes encoding the enzymes for $\mathrm{N}$-glycosylation identified multiple genes in ticks, including A. americanum, that were orthologous to those of insects and humans (64). In addition, a number of galactosyltransferase homologs in the Ixodes scapularis tick were identified that are involved in the production of $\alpha$-gal in tick salivary glands and increase after feeding (61). Other possibilities for $\alpha$-gal sources include bacteria present in ticks. For example, the tick-borne bacteria Anaplasma phagocytophilum and Borrelia burgdorferi sensu lato express $\alpha$-gal (60), which may drive $\alpha$-gal-specific IgE production by increasing $\alpha$-gal levels in ticks as well as contributing to the immune response. Differences in the microbiome among tick species may determine the presence of $\alpha$-gal and therefore the tick microbiome is postulated to be a risk factor influencing the development of meat allergy. Further investigating this theory might prove to be challenging, but genomic and transcriptomic sequencing approaches to identify GT genes that are expressed by the microbes living inside ticks may provide supporting evidence for $\alpha$-gal biosynthesis.

\section{IGE IMMUNE RESPONSES IN ALLERGY}

Allergies involve both innate and adaptive immune responses. The topic of innate immune responses in allergy is not discussed here, but excellent reviews can be found elsewhere (65-67). The initial encounter with allergen occurs at the epithelial barrier such as the lung epithelia for air allergens, the gut epithelia for food allergens, and the skin epithelia for insect venom allergens. Epithelial cells and tissue resident innate immune cells are known to play an important role in inducing cytokines that favor host $\mathrm{T}$ helper 2 cell (Th2) responses. In addition, dendritic cells (DC) play an important role in initiating the adaptive immune response to allergen. DCs present antigen to T cells and provide costimulatory signals that are vital to activating these $\mathrm{T}$ cells. Upon antigen binding, tissue resident DCs traffic to the draining lymph nodes, where they present antigen to $\mathrm{T}$ cells and drive Th2 cell differentiation (68-71). Early work on IgE regulation demonstrated an important role for Th2 cells, as deletion of Th2 lineage-defining transcription factors such as STAT6 or GATA3 reduced IgE production (72-74). In addition, deletion of the canonical Th2 cytokine IL-4 reduces IgE. Recent studies have demonstrated that IL- $4^{+}$T follicular helper (Tfh) cells, essential for germinal center (GC) formation in secondary lymphoid organs, are required for IgE production (75-80). Moreover, a rare subset of IL- $4^{+}$Tfh cells that produces IL-13 has been identified and induces high-affinity IgE to allergens (81).

Although little is known about how tick bites drive the IgE response of allergen-specific B cells, multiple studies have shown that Th2 responses are induced by tick saliva-considered by some in the field to be a special kind of venom (82). Tickderived factors that drive Th2 responses are thought to facilitate transmission of tick-borne pathogens that would otherwise be neutralized by Th1 cell-mediated responses. Human and mouse $\mathrm{CD}^{+}{ }^{+} \mathrm{T}$ cells produce $\mathrm{Th} 2$ cytokines in response to tick saliva, including IL-4 and IL-13, with reduced production of the Th1 cytokine IFN $\gamma(83-89)$. Many of the factors in tick saliva thought to play a key role in shaping the innate immune response for inducing Th2 responses include prostaglandins, sphingomyelinase, and cysteine protease inhibitors (90-93). These factors could influence the pattern of $\mathrm{CD}^{+} \mathrm{T}$ cell responses by acting on antigen presenting cells to create a cytokine milieu that favors the development of Th2 cells while suppressing Th1 differentiation (94). In addition, these factors could directly act on B cells to enhance class switch recombination to IgE. This notion is supported by increased production of IgE in mice treated with the prostaglandin, PGE2 (95), and from murine B cells stimulated with LPS plus IL-4 in the presence of PGE2 (96-99). However, non-polarized or mixed Th1 and Th2 responses are also observed following tick bites $(100,101)$. These differences could reflect the tick species, the community of microbiota living inside the ticks, or temporal changes in the tick saliva-derived factors throughout the duration of feeding, including protein changes in the saliva of lone star ticks as previously reported (102-105). Meat allergic patients show a Th2-skewed profile, as measured by higher $\alpha$-gal IgE, IgG1 and IgG4 levels (106). This suggests that tick bites of affected individuals drive sensitization to $\alpha$-gal by promoting Th2-mediated immune responses, possibly through induced antibody class switching by tick salivary PGE2, leading to an increase in the frequency of $B$ cells producing $\alpha$-gal-specific $\operatorname{IgE}(107)$. 


\section{B Cell Differentiation Pathways to IgE}

Recent studies using IgE-reporter mice support two differentiation pathways for the generation of IgE-secreting plasma cells (PC). The first is that $\operatorname{IgE}^{+}$PCs develop from the responding progeny of $\mathrm{GC}$-derived $\mathrm{IgE}^{+} \mathrm{B}$ cells and $\mathrm{IgE}^{+}$ memory B cells that are directly derived from $\operatorname{IgM}^{+}$naïve $\mathrm{B}$ cells (108). The second is that $\operatorname{IgE}^{+}$PCs develop through indirect isotype switching from the responding progeny of GC-derived $\mathrm{IgG1}^{+} \mathrm{B}$ cell intermediates and from $\mathrm{IgG1}^{+}$memory B cells following antigen exposure $(109,110)$. The indirect isotype switching pathway results in IgE that has a higher affinity for antigen due to greater levels of somatic hypermutation in positively selected memory B cells and PCs. However, it should be noted that GC-independent $\mathrm{IgE}^{+} \mathrm{B}$ cell responses have also been observed through mechanisms that remain unknown (111). Further work is needed to elucidate the processes of GC-independent differentiation of IgE-producing PCs and to determine its contribution to the development of pathogenic IgE in allergy.

In humans, the biology of IgE-expressing B cells remains enigmatic, mainly because of their scarcity and the lack of robust assays that allow for comprehensive immunophenotyping of rare $\mathrm{IgE}^{+} \mathrm{B}$ cells. The half-life of IgE in serum is short (i.e., 2-3 days), but the capacity to regenerate allergen-specific $\operatorname{IgE}$ and develop food allergies are lifelong in the majority of patients. This suggests the existence of long-lived, allergen-specific memory B cells (MBC) established at the time of sensitization, which replenish the short-lived IgE-secreting cells on allergen re-exposure (112). $\mathrm{IgE}^{+} \mathrm{MBCs}$ are found at extremely rare frequencies in the blood of healthy donors, atopic donors, and donors with food allergy $(111,113,114)$. Some studies suggest that the reservoir of IgEproducing cells instead resides in MBCs of a non-IgE isotype $\left(\mathrm{IgM}^{+}\right.$or $\left.\operatorname{IgG}^{+}\right)$(112). Class-switching to IgE in these memory $\mathrm{B}$ cells is thought to take place in germinal centers (115), with indirect isotype switching of IgG-expressing B cells to IgE found more prevalent both in healthy and allergic subjects compared to direct IgE switching $(116,117)$.

A number of studies have examined the sequences of $S \mu$ $S \varepsilon$ switch regions in allergic individuals and found that these regions contained $S \gamma$ switch region remnants, suggesting that IgE was generated through indirect isotype switching $(111,117-$ 120). Moreover, common lineages in $\mathrm{IgGl}^{+}$and $\mathrm{IgE}^{+} \mathrm{B}$ cells have been found in human subjects when analyzing the repertoire of the rearranged immunoglobulin genes (117), supporting the view that IgE was generated through an indirect switching pathway. In contrast, studies analyzing somatic hypermutation and the correlation between different antibody isotypes in patients with allergies to house dust mite and the fungus Alternaria alternata suggest that IgE is derived through direct switching from IgM to IgE (121). Moreover, a population of unswitched, $\operatorname{IgM}^{+}$MBCs that have undergone somatic hypermutation have been described in humans (122-124). These $\operatorname{IgM}^{+} \mathrm{CD} 27^{+}$cells are long-lived (125), and rapidly differentiate into antibody-secreting cells following stimulation $(126,127)$. Limitations in human studies, including low frequency of $\mathrm{IgE}^{+}$cells in the circulation and inability to assess class switch recombination in vivo following allergen challenge, have so far prevented the resolution of these conflicting data and the contribution of direct and indirect switching in the production of pathogenic IgE.

Given these limitations in human studies, many groups have turned to mouse models to study the contribution of direct vs. indirect switching to IgE production. Similar to the methods used in the human studies noted above, S $\gamma 1$ fragments within $S \mu-S \varepsilon$ switch regions have been detected in mice (109). This study found that the frequency of $S \mu$ $S \varepsilon$ switch regions containing $S \gamma 1$ fragments increased with repeated immunization, as did the affinity of $\operatorname{IgE}$ antibodies for antigen, suggesting that indirect switching was necessary for the production of $\mathrm{IgE}^{+} \mathrm{B}$ cells with high-affinity for antigen. This conclusion was further supported by reduced levels of somatic hypermutation and affinity maturation of IgE antibodies produced by mice that were unable to produce IgG1. These data conflict with an earlier study (128), in which mice with impaired switching to IgG1 exhibited no defect in the primary or secondary IgE response to infection with the helminth, Nippostrongylus brasiliensis, or immunization with the protein antigen, 4-hydroxy-3-nitrophenylacetyl-ovalbumin (NP-OVA). However, the affinity of the IgE antibodies generated in this study was not assessed, and further characterization of IgE produced in these mouse models could resolve the discrepancy between these two studies.

\section{Longevity of $\operatorname{lgE}^{+}$Plasma Cells}

Another key aspect of allergic memory that remains unclear is the development of long-lived IgE-secreting PCs. Long-lived IgGsecreting PCs have been detected in both humans and mice, and play a vital role in maintaining humoral immunity (129). These cells are maintained in survival niches, often in the bone marrow, continuously secreting protective IgG antibodies for years (130). Murine studies have been employed to investigate the development of long-lived IgE-secreting PCs, as the bone marrow and other lymphoid organs can be easily probed for these cells. It has been shown that long-lived $\operatorname{IgE}^{+}$PCs are generated during the allergic response to OVA (131). IgE-secreting PCs were detected in the bone marrow of immunized mice a month after challenge, far beyond when short-lived PCs in the draining lymph node have declined. These bone marrow $\operatorname{IgE}^{+}$PCs were resistant to treatment with cyclophosphamide, indicating that these cells had exited the cell cycle which is a hallmark of long-lived PCs (132). Experiments in IgE-reporter mice also support the notion that long-lived $\operatorname{IgE}^{+}$bone marrow plasma cells are generated during the allergic response $(108,133)$. Allergen-specific IgE produced from bone marrow PCs was capable of inducing anaphylaxis in mice with chronic house dust mite exposure (133). In contrast, only short-lived $\mathrm{IgE}^{+} \mathrm{PCs}$, found in the draining lymph node, were detected in Verigem mice following challenge with allergen (134). The use of different genetic modifications of the IgE locus, adjuvants, and routes of sensitization in the murine studies detailed above may account for the conflicting conclusions about the development of long-lived $\operatorname{IgE}^{+}$PCs.

Several clinical observations suggest that long-lived $\mathrm{IgE}^{+} \mathrm{PCs}$ develop in patients with allergy. Low levels of allergen-specific $\operatorname{IgE}$ are chronically found in the serum of atopic individuals, even in the absence of exposure to allergen (131). Additionally, 
transfer of peanut allergy from donor to recipient following bone marrow transplant has been reported multiple times (135137), suggesting that the bone marrow of donor allergic patients contains long-lived, allergen-specific $\mathrm{IgE}^{+}$PCs. Monoclonal antibody-mediated depletion of $\mathrm{IgE}^{+} \mathrm{B}$ cells in atopic patients reduces serum IgE but not to baseline levels, thereby indicating enduring cellular sources of $\operatorname{IgE}$ production $(138,139)$. Finally, $\mathrm{IgE}^{+} \mathrm{PCs}$ were recently found in bone marrow of three catallergic patients that secreted detectable levels of total and cat dander-specific IgE and caused mast cell degranulation (133). In summary, these findings provide evidence that human $\mathrm{IgE}^{+} \mathrm{PCs}$ reside in the bone marrow and secrete $\mathrm{IgE}$ capable of triggering an allergic response in at least some atopic patients. Efforts to further characterize these cells and resolve whether $\mathrm{IgE}^{+} \mathrm{PCs}$ in the bone marrow is broadly shared in allergy will be needed to devise new treatment strategies to target the cellular sources of allergen-specific IgE.

\section{B CELL RESPONSES IN MEAT ALLERGY}

In meat allergic patients, the mechanisms by which tick bites sensitize individuals to tick antigens such as $\alpha$-gal are unknown. Given that $\alpha$-gal exposure alone does not induce an IgE response $(140,141)$, two hypotheses have been proposed for the production of $\alpha$-gal-specific IgE. One is that the presence of $\alpha$-gal in the context of tick-derived immunomodulatory factors cause antibody class switching to IgE in pre-existing $\alpha$-gal-specific $\mathrm{IgM}^{+}$or $\mathrm{IgG}^{+} \mathrm{B}$ cells. The other is the presentation of $\alpha$-gal to the immune system following a tick bite activates mature $\alpha$ gal-specific $B$ cells to differentiate into memory cells which later undergo class switch recombination to IgE. Given the ethical aspects of exposing humans to ticks, many groups have turned to animal models to study the underlying immune mechanisms of tick-borne diseases.

\section{IgE Production in Mice That Develop Meat Allergy-Like Disease}

The host immune response to A. americanum was first tested in guinea pigs (142). This study found that guinea pigs acquired resistance to the recurrent feeding of lone star ticks, which resulted in dermal cellular infiltration in lesions around the tick bites with the accumulation of granulocytes, including basophils. However, A. americanum has not yet been used to test IgEmediated hypersensitivity responses and the underlying immune mechanisms of disease development. Recent work from our group shows that a mouse model can recapitulate features of meat allergy in humans (143). In this study, repeated cutaneous exposure to lone star tick protein antigens, to mimic the natural route of tick bites, leads to the development of red meat allergylike disease in mice (Figure 1A). The disease is characterized by high titers of serum IgE antibodies, local inflammation at the site of antigen exposure (e.g., dermal thickening; vasculitis and muscle fiber atrophy; infiltration of granulocytes, lymphocytes, and plasma cells within the dermis and hypodermis), and a systemic hypersensitivity response in tick-immunized mice after eating meat (e.g., increased frequencies, activation, and histamine release of basophils in blood; greater serum mast cell protease- 1 levels). Although our report used beef thyroglobulin to induce in vivo allergic hypersensitivity reactions, other in vitro systems have used $\alpha$-gal bound to beef proteins or lipids to test allergic reactions. Román-Carrasco et al. reported that only $\alpha$-gal bound to lipids, but not to proteins, crossed a monolayer of intestinal cells and activated basophils from a patient with meat allergy (Figure 1B) (144). Why $\alpha$-gal-containing beef protein enhanced basophil activity in our study but had no effect in the referenced report is unclear; however, different experimental systems were used with distinct assays to measure mouse and human basophils. As such, a direct comparison cannot be made that controls for other confounders.

Our model is unique in that wild type mice and mice deficient in the $\alpha$-1,3-galactosyltransferase gene (GT KO) are used. Wild type mice synthesize $\alpha$-gal epitopes and therefore naturally do not produce $\alpha$-gal-specific antibodies because of immune tolerance, whereas GT KO mice are not immune tolerant to $\alpha$ gal. After tick antigen exposure, both wild type and GT KO mice produce tick protein-specific IgE antibodies but only GT KO mice produce $\alpha$-gal-specific IgE. Interestingly, dogs, which also synthesize $\alpha$-gal, have detectable levels of $\alpha$-gal-specific IgM and IgG that increase after tick infestation without affecting $\operatorname{IgE}(60)$. These findings are consistent with our results in wild type mice that do not produce $\alpha$-gal-specific IgE after cutaneous exposure to tick antigens, suggesting that immune tolerance may prevent $\alpha$-gal sensitization. Both local inflammation in the skin around antigen exposure and hypersensitivity responses are greater in GT KO mice compared with wild type mice, which are phenotypes analogous to human meat allergy (143). Importantly, the development of an IgE response in mice is dependent on cutaneous tick exposure as other routes of tick antigen exposure fail to induce IgE, which is in keeping with evidence in humans that sensitization to $\alpha$-gal requires skin exposure. Consistent with the above findings, it was also demonstrated that subcutaneous injection of saliva obtained from the Brazilian Amblyomma sculptum tick induced $\alpha$-gal-specific IgE production in GT KO mice (29). This study provides additional evidence for a link between mammalian meat allergy and bites from other tick species.

Our work further demonstrated that cutaneous exposure to tick antigens induced $\mathrm{T}$ follicular helper cells and GC B cells in the skin draining lymph nodes. $\mathrm{CD} 4^{+} \mathrm{T}$ cell help was required for sensitization to produce IgE antibody responses, as total and tick-specific IgE levels were reduced in mice depleted of $\mathrm{CD} 4^{+}$ $\mathrm{T}$ cells or when treated with a CD154 mAb to block GC B cell formation (143). Interestingly, the development of host resistance to A. americanum first reported in guinea pigs was associated with germinal center formation in the lymph nodes draining tick feeding sites (142).

Tick protein antigens had an adjuvant effect in our mouse model for IgE production, suggesting that, in addition to allergen exposure, the presence of other immunomodulatory factors is required for sensitization. Analysis of lone star tick protein antigens using a commercial toll-like receptor (TLR) screen indicated that ligands for TLR2, TLR4, TLR5, and to a lesser degree, TLR9, were present. Notably, all of these TLRs signal 


\section{A In vivo experimental system}

A. americanum

Beef thyroglobulin

protein extract

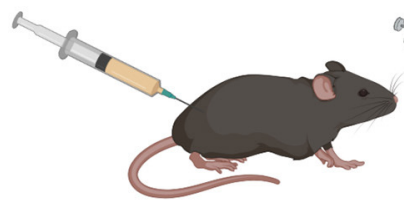

Wild type mice

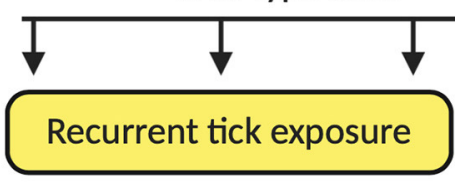

Route Route Route

Cutaneous

Cutaneous

\section{solution}

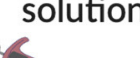

and

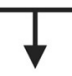

Allergen

Route

Oral
Flow cytometry
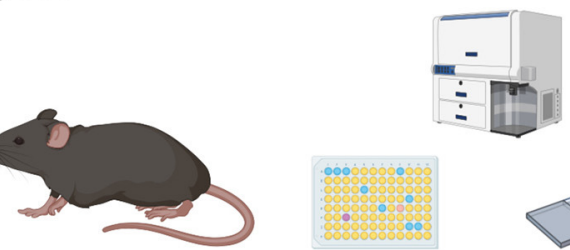

GT knockout mice

B

In vitro experimental system

Beef lipid and protein extract preparations
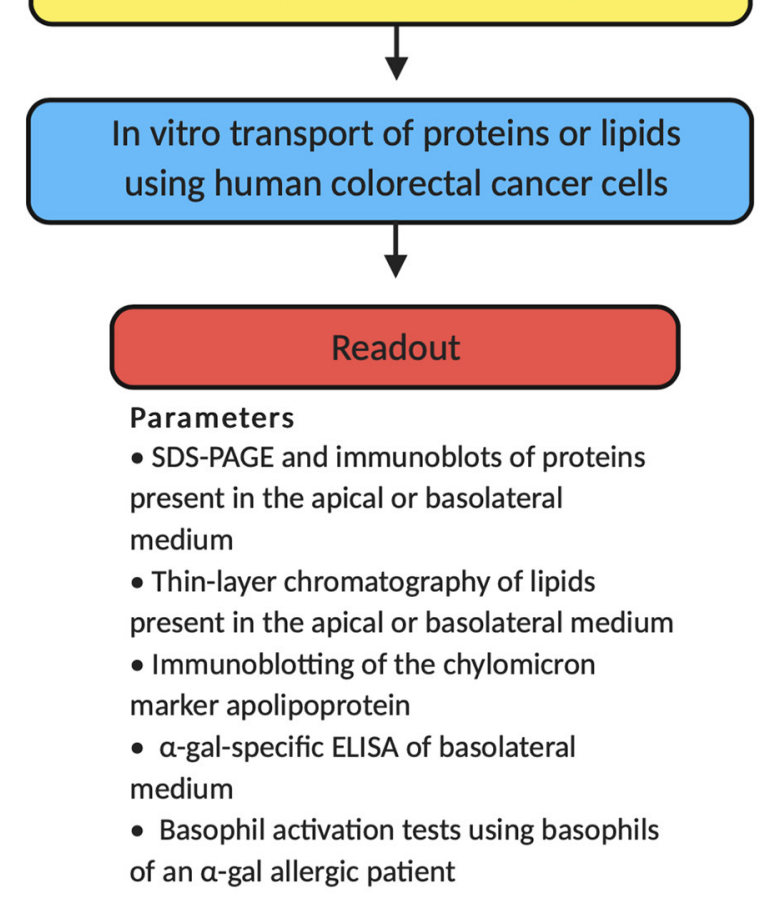

FIGURE 1 | Schematic overview of the in vivo and in vitro experimental approaches employed to test the immune mechanisms by which $\alpha$-gal induces an IgE-mediated immune response. (A) Development of meat allergy to A. americanum in wild type mice and mice deficient in the $\alpha$-1,3-galactosyltransferase (GT) gene. (B) $\alpha$-gal from meat is transported across enterocytes and activates basophils through $\alpha$-gal-specific lgE. 


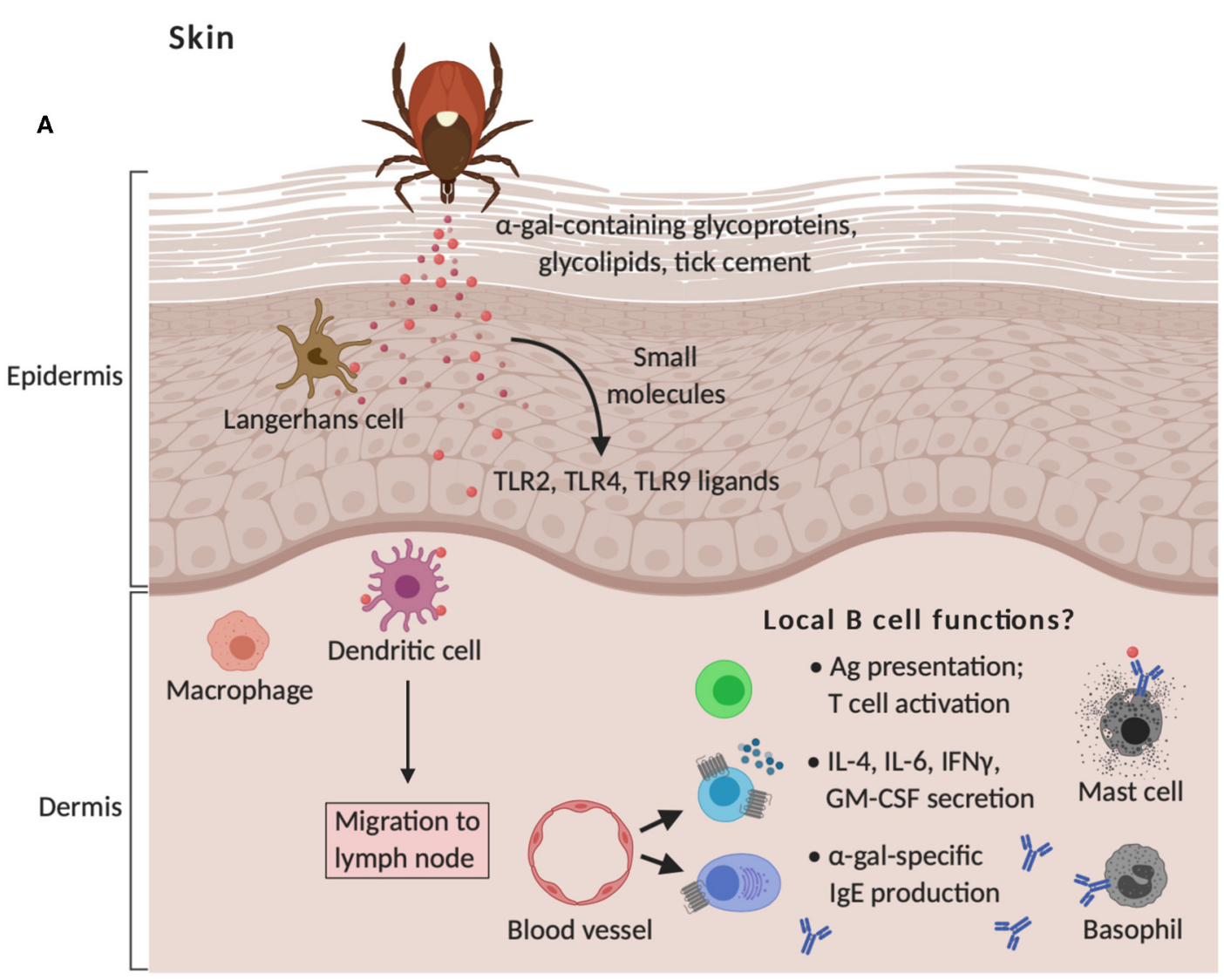

B

\section{Skin-draining lymph node}

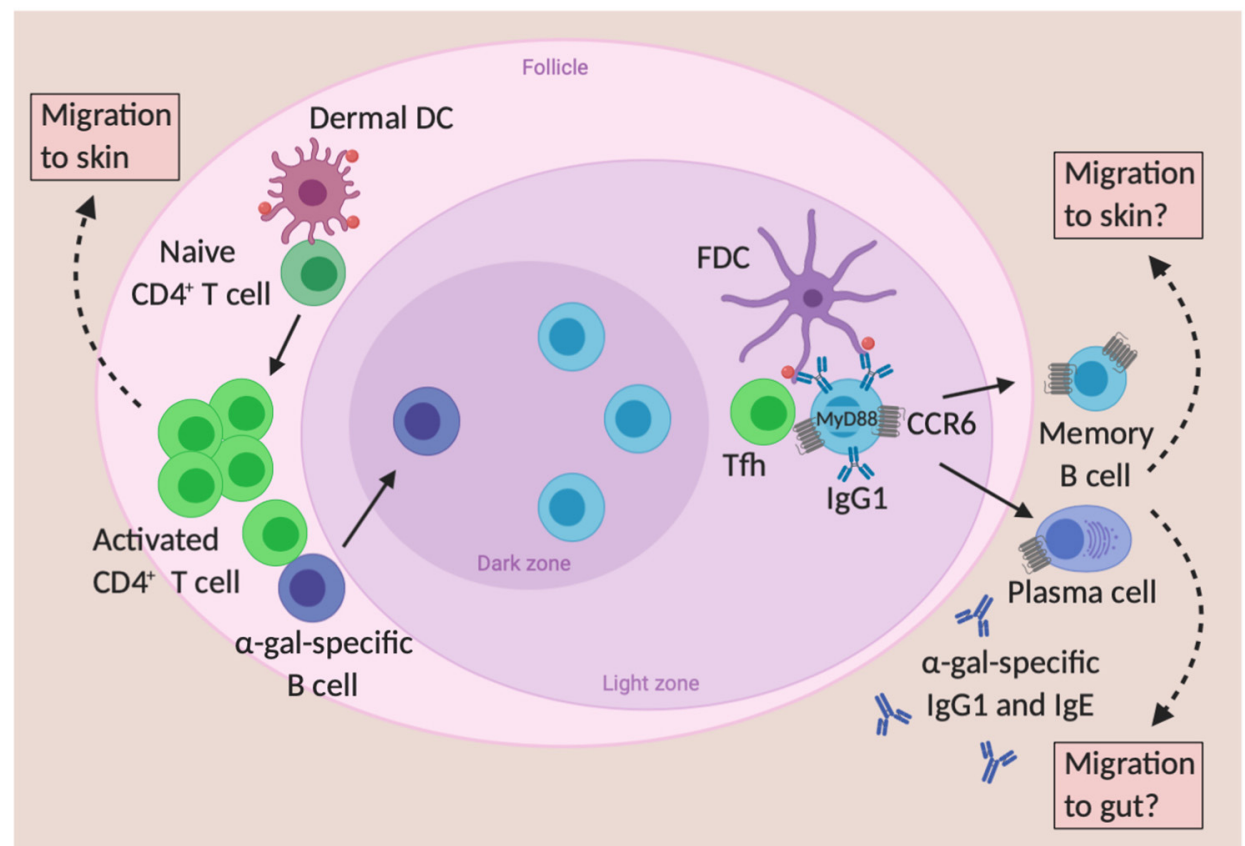

FIGURE 2 | Proposed model of skin-associated B cell functions in $\alpha$-gal sensitization from tick bites. (A) The skin is comprised of the epidermis and the dermis that are separated by a basement membrane. Langerhans cells (LC) and dermal dendritic cells (DC) are capable of responding to cutaneous exposure of tick antigens, 
FIGURE 2 | such as glycoproteins, glycolipids, and tick cement that contain $\alpha$-gal moieties, which leads to the migration of these cells to the skin-draining lymph nodes and allergen sensitization. This response is also shaped by the migration of B cells to inflamed skin around the tick bite, which may contribute to allergic responses by presenting antigen to $T$ cells, secreting pro-inflammatory cytokines, and secreting IgE antibodies that trigger mast cell and basophil activation. To date, the role of skin-associated B cells in meat allergy is unknown. (B) Naîve T cells are primed via presentation of tick antigens by LCs and dermal DCs within skin-draining lymph nodes. Activated CD4 ${ }^{+} \mathrm{T}$ cells subsequently traffic to the skin through blood and lymphatic vessels. Cognate T cell help provided by $T$ follicular helper (Tfh) cells to $\alpha$-gal-specific B cells leads to germinal center responses, positive clonal selection of B cells via recognition of native antigens retained by follicular dendritic cells (FDC), and the development of memory B cells and plasma cells that express skin- and gut-homing CCR6 receptors. IgE production to cutaneous tick antigens functions through a B cell-intrinsic myeloid differentiation primary response protein 88 (MyD88) pathway and indirect class switching of lgG1+ B cells to lgE.

through the protein encoded by the myeloid differentiation primary response gene 88 (MyD88) (145). We found that MyD88 expression was required for the IgE response to cutaneous tick antigen exposure, as total and tick-specific IgE production was reduced in the absence of MyD88. Moreover, reduced levels of IgE antibodies were observed in mice that conditionally delete MyD88 in B cells that have class switched to IgG1. Together, the above findings support a model where allergen-specific $B$ cells are stimulated through the MyD88 signaling pathway in germinal centers to produce IgE, with indirect class switching of IgG1-expressing B cells to IgE (Figure 2). MyD88 has been shown to be involved in Th1 cell responses (145); however, more recent work has demonstrated that MyD88 signaling also plays a role in Th2 cell-mediated responses (146-148). Because signaling through TLR2, TLR4, and TLR9 has modulatory effects on the mucosal immune system and has been shown to induce IgE production (149-151), it is possible that A. americanumderived TLR2-, TLR4-, and TLR9-activating small molecules exert host adverse effects by promoting skin inflammation at the tick bite site. This might aid in the activation of pre-existing $\alpha$ gal-specific $B$ cells and sensitization to tick antigens, although this has yet to be formally tested. This notion is supported by recent observations that several allergens contain TLR ligands and activate MyD88 signaling in innate and adaptive immune cells, suggesting an important role of distinct pathogen-associated molecular patterns in the development of allergy (148, 152-155). However, TLRs are not the only immune receptors to signal through MyD88. Members of the IL-1 receptor family, including IL-1R, IL-18R, and IL-33R, also signal through MyD88 (156). These observations raise the possibility that signals through these receptors on innate and adaptive immune cells could be used to drive allergic sensitization to tick antigens and require further investigation. A new zebrafish animal model for the study of allergic reactions in response to tick saliva and red meat consumption has recently been developed that might be useful in this pursuit (157). Zebrafish do not express $\alpha$-gal in their tissues and produce $\alpha$-gal-specific IgM, similar to humans. Interestingly, allergic reactions in zebrafish manifest only when previously exposed to tick saliva and are associated with tissue-specific TLR-mediated responses in Th1 and Th2 cells.

Small molecules within tick saliva are known to exhibit immunomodulatory effects on a wide variety of both skin resident and infiltrating cell types, facilitating local and systemic responses (158). For example, salivary molecules from multiple tick species have been identified that impede natural host hemostatic responses to tick bite-induced tissue damage, promoting vasodilation and countering platelet aggregation, angiogenesis, and the coagulation cascade (159-165). The saliva from ticks also has anti-inflammatory effects that might favor a Th2 immune response. For example, saliva from Rhipicephalus appendiculatis ticks prevents inflammation by impairing the secretion and function of certain soluble mediators, such as histamine (166). Saliva from Rhipicephalus sanguineus ticks inhibits the migration of dendritic cells into and out of the skin, reducing antigen presentation to $\mathrm{T}$ cells in draining lymph nodes (101). Saliva from the tick Ixodes ricinus contains proteins of the lipocalin family that inhibit the host inflammatory response in vivo by decreasing the number and activation of neutrophils in the skin around the tick bite site (167). Finally, gene expression profiling of cutaneous bite-site lesions in mice from the tick Ixodes scapularis shows increased expression of anti-inflammatory molecules such as IL-10, SOCS1, SOCS3, and the regulatory $\mathrm{T}$ cell-associated Forkhead box P3 (FOXP3) transcription factor early $(<3 \mathrm{~h})$ after tick attachment (100). However, by $12 \mathrm{~h}$ after tick attachment, an inflammatory response develops as measured by the upregulation of transcripts for IL1 $\beta$, IL-6, CCL2, and CCL7, that facilitate local recruitment of neutrophils, degranulation of mast cells, and muscle necrosis at the tick bite site (168). These studies suggest that there is at least some degree of pro- and anti-inflammatory response mounted following tick bites. Interestingly, with the exception of I. ricinus, none of the above-mentioned tick species are linked to mammalian meat allergy. It is therefore possible that microbial ligands within tick saliva might be differentially expressed and recognized by host immune cells during tick bites.

How the skin route of tick exposure initiates allergic sensitization to food allergens such as $\alpha$-gal and evades oral tolerance is poorly understood. The skin is an important barrier organ and integral component of the immune system that protects the body from external insults, but it is also a target for allergic disease. Skin barrier disruption and cutaneous exposure to food allergens in particular are strongly associated with food allergy (169-171). Thus, it has been hypothesized that sensitization to food allergens can occur through damaged skin, leading to Th2 immune responses in the draining lymph node and the production of systemic allergen-specific IgE antibodies that characterize allergic disease. There is limited knowledge of the role for skin-associated B cells in this process, where they may perpetuate local inflammation by enhancing cutaneous allergenspecific IgE titers. In many chronic inflammatory human diseases that have been presumed to be driven by $\mathrm{T}$ cells, such as atopic dermatitis (172), psoriasis (173), pemphigus (174), cutaneous lupus (175-177), allergic contact dermatitis (178), and scleroderma (179), B cells accumulate in inflamed skin. Many 
roles for B cells have been postulated in these diseases beyond their contributions to pathogenic antibody production, including their ability to present antigen and secrete pro-inflammatory cytokines, like IL-6, GM-CSF, IFN- $\gamma$, all of which promote local inflammation (180). In addition, cellular compartments called tertiary lymphoid structures (TLS) that support interactions between skin $\mathrm{B}$ and $\mathrm{T}$ cells are found in sites of chronic inflammation $(174,181)$. These structures are variable and can be mature, forming germinal centers that might facilitate B cell function, or immature, that do not form GCs and therefore may not support B cell function. Mature TLS in the skin might provide a local microenvironment for skin-associated B cells to promote inflammation by enhancing pathogenic antibody production and $\mathrm{T}$ cell activation. In contrast, $\mathrm{B}$ cells in skin can produce inhibitory factors that suppress activation of other leukocytes. $B$ regulatory cells that produce IL-10 have been found in skin and limit cutaneous inflammation in mouse models of psoriasis and contact hypersensitivity (182-184). Thus, skin-associated B cells are a heterogenous population of discrete $B$ cell subsets that can drive or suppress inflammatory responses. Interrogating B cells quantitatively in disease tissue, what they secrete, and what cells these B cells physically interact with are key approaches that could help predict a patient's response to tick bites and establish new immune-based therapies to block allergic sensitization.

Our own observations of inflamed skin at the site of tick antigen exposure demonstrate the accumulation of leukocytes, with greater numbers of $\mathrm{CD} 4^{+} \mathrm{T}$ cells, B cells, and plasma cells found in immune GT KO mice compared to naïve controls (143) and unpublished observations. Strikingly, these B cells express high levels of the chemokine receptor CCR6 and have an activated phenotype as measured by increased expression of MHCII and CD86 levels. Increased frequencies of CCR6 $6^{\text {high }}$ B cells are also found in skin draining lymph nodes and Peyer's patches in the gut of the same mice. Expression of CCR6 on B cells is associated with migration both to Peyer's patches, major sites of circulating $\mathrm{B}$ cell homing and activation by intestinal antigens $(185,186)$, and from skin draining lymph nodes to the skin (187). CCR6 and its ligand, CCL20, also can contribute to skin and gut homing of T cells (188-190). These data support the notion that tick antigen-specific CCR6 $6^{\text {high }} \mathrm{B}$ cells are generated in the skin draining lymph node before trafficking to inflamed skin and to the gut where they may encounter $\alpha$-gal and further differentiate into IgE-secreting cells (Figure 2). Ongoing studies are aimed to formally test this hypothesis. An implication of this hypothesis is that if the skin inflammation mediated by tick bites can be prevented, $\alpha$-gal-specific IgE production could be impaired and the incidence of meat allergy might be decreased. This represents a substantial shift in thinking concerning the target organ for food allergy prevention.

\section{B Cell Responses in Human Meat Allergic Patients}

Our findings linking cutaneous lone star tick exposure and $\alpha$-galspecific IgE production with meat allergy development in mice prompted us to ask whether distinct $\operatorname{IgE}^{+} \mathrm{B}$ cell phenotypes are enriched in individuals with meat allergy following tick bites. Our recent work using high-dimensional mass cytometry indicates that four main B cell subsets are significantly enriched in the blood of meat allergic patients compared with non-meat allergic controls (191). These B cell subsets share high expression levels of CCR6 in keeping with findings from our mouse studies. They do not share typical characteristics of classical isotypeswitched memory B cells that express IgG and high levels of CD27 $(123,126)$, with B cells expressing IgM or IgD and low or high levels of CD27. Testing the capacity of these B cell subsets to secrete antibodies following in vitro stimulation demonstrated that such cells undergo isotype-switching and produce $\alpha$-galspecific IgE in patients with meat allergy but not in healthy control subjects (191). The specific role of direct vs. indirect class switch recombination to IgE was not tested in this study, and further work is necessary to determine the mechanisms of clonal selection and the ontogeny of $\alpha$-gal-specific B cells. These B cells may include a novel population of memory cells lacking CD27 expression found in the blood that are prone to differentiate into IgE-secreting cells $(192,193)$. Memory B cells displaying low to negative CD27 expression are also found in human tissues near epithelial surfaces $(194,195)$. Early work in human adults identified peripheral blood memory B cells that express IgM with or without IgD, or express IgD only (122, 123, 196-198); these cells show somatically mutated $\mathrm{IgV}$ genes suggesting the involvement of $\mathrm{T}$ cell help for their development. Together, the above findings support a novel $\mathrm{B}$ cell signature in meat allergic subjects that associates with $\alpha$-gal-specific IgE production, which may play a role in the pathogenesis of this food allergy.

This B cell signature might help explain the positive association of subjects who do not express the blood group B antigen among those with mammalian meat allergy $(5,199)$. Because the molecular structure of $\alpha$-gal is closely related to the $B$ antigen (45), it has been hypothesized that patients expressing the $\mathrm{B}$ antigen are tolerant to $\alpha$-gal and therefore protected from allergic sensitization to $\alpha$-gal. Patients with the B antigen produce less $\alpha$-gal-specific IgE compared with those without the B antigen $(199,200)$, and is associated with reduced Th2-like IgG1 and IgG4 antibody responses to $\alpha$-gal $(106,200)$. We theorize that tick bites present $\alpha$-gal to the immune system in a context that elicits the activation and persistence of memory B cells to $\alpha$ gal from which $\alpha$-gal-specific IgE is derived under control of $\mathrm{T}$ cell help. Although subjects who express the $\mathrm{B}$ antigen can be sensitized to $\alpha$-gal and develop meat allergy, those who do not express the $\mathrm{B}$ antigen may have stronger Th2 responses that cause recall of distinct B cell memory subsets to $\alpha$-gal. This possibility may also affect the increased susceptibility to infectious diseases caused by pathogens carrying $\alpha$-gal on their surface, such as malaria and tuberculosis, in individuals with the B antigen (58). Identifying the immune profile of $\mathrm{CD} 4{ }^{+} \mathrm{T}$ cell subsets from meat allergic patients with and without $\mathrm{B}$ antigen and the functional capacity of each subset to induce activation of B cell subsets could help instruct the relationship between memory B cells, blood group B antigen, and $\alpha$-gal sensitization. This knowledge could help to shape strategies for improved vaccines for human pathogens that display $\alpha$-gal. Several $\alpha$-gal-based vaccines have enhanced humoral and/or cell-mediated responses to Leishmania and Trypanosoma cruzi that have membrane-expressed $\alpha$-gal 
epitopes, using the GT KO mouse model (54-56). Additionally, this information might provide clues how $\alpha$-gal can increase the immunogenicity of viral vaccines designed to express $\alpha$ gal epitopes, including flu vaccine, for effective targeting of the vaccine to antigen presenting cells, thereby increasing its efficacy (201).

Whether the circulating B cell subsets found in meat allergic patients migrate to inflamed skin during tick bites is unknown. In studies examining immune cells locally in skin at the lone star tick bite site, migratory B cells and T cells were implicated in meat allergic patients within 2 days after tick bites (202). Comparison of serum IgE titers from a meat allergic subject obtained 5, 14, and 35 days after tick bites showed increased total and $\alpha$-gal-specific IgE (3). These findings indicate that $\alpha$ gal IgE is rapidly induced following tick bites, suggesting a link between cutaneous exposure to $\alpha$-gal coupled with inflammatory signals and the activation of pre-existing $\alpha$-gal-specific B cells in meat allergic subjects. Based on these findings, we hypothesize that skin-associated B cells at the tick bite site contain a highly expanded, $\alpha$-gal-specific B cell population that contributes to the initiation and maintenance of meat allergy via production of IgE. Ongoing human and mouse studies by us and other groups should inform whether B cells locally produce IgE to promote inflammation, their developmental pathways, and how these cells can be targeted therapeutically.

\section{CONCLUDING REMARKS AND OPEN QUESTIONS}

Within the past few years, we have started to gain new information about how specific host- and tick-derived molecules shape the adaptive immune response to ticks associated with mammalian meat allergy. Continued research into the specific mechanisms by which tick bites trigger $\alpha$-gal sensitization is important for devising new therapeutic strategies to treat and prevent this allergy. The skin contains many innate and adaptive immune cell types including DCs, macrophages, mast cells, innate lymphoid cells, T cells, and B cells. B cells have a major role in protection against pathogens through antibody production but also through antigen presentation and cytokine production. B cell function also influences the activity of other immune cell types. In this aspect, knowing how B cells respond to tick-derived antigens and immunomodulatory factors and migrate to the skin

\section{REFERENCES}

1. Commins SP, Satinover SM, Hosen J, Mozena J, Borish L, Lewis BD, et al. Delayed anaphylaxis, angioedema, or urticaria after consumption of red meat in patients with IgE antibodies specific for galactose-alpha-1,3-galactose. $J$ Allergy Clin Immunol. (2009) 123:426-33. doi: 10.1016/j.jaci.2008.10.052

2. Van Nunen SA, O'Connor KS, Clarke LR, Boyle RX, Fernando SL. An association between tick bite reactions and red meat allergy in humans. Med J Aust. (2009) 190:510-1. doi: 10.5694/j.1326-5377.2009.tb02533.x

3. Commins SP, James HR, Kelly LA, Pochan SL, Workman LJ, Perzanowski MS, et al. The relevance of tick bites to the production of $\operatorname{IgE}$ antibodies to the mammalian oligosaccharide galactose-alpha-1,3-galactose. J Allergy Clin Immunol. (2011) 127:1286-93. doi: 10.1016/j.jaci.2011.02.019 and gut will be important for controlling tick-borne allergies. Several major questions still remain that need to be addressed to generate a complete picture:

1. The contribution of skin-associated B cells to the generation of $\alpha$-gal-specific IgE. Since B cells are expanded in inflamed skin in several other allergy and autoimmune diseases, this knowledge might be broadly applicable to fundamental B cell biology in several disease contexts beyond meat allergy.

2. Determining the relationships between $\alpha$-gal-specific IgM and IgG antibodies, and the B cell populations that produce them, to $\alpha$-gal-specific IgE. Evaluating the antibody repertoire in patients with meat allergy by analyzing B cell receptor clonality, use of Ig heavy chain variable region genes, affinity maturation to $\alpha$-gal, and isotype use would provide a more detailed understanding of how $\alpha$-gal IgE antibodies are generated.

3. Understanding how cutaneous exposure to $\alpha$-gal and other tick-derived molecules leads to the loss of oral tolerance. This will require development of models that allow testing of specific molecules identified in tick saliva and the capacity to probe innate and adaptive immune cell dynamics in a temporal manner in the skin and GALT.

4. Deciphering why certain tick species associate with mammalian meat allergy while others do not. Ideally this should integrate microbiome analyses with proteomics of tick saliva and gastrointestinal tract to identify bacterial compositions and the expression of $\alpha$-gal.

\section{AUTHOR CONTRIBUTIONS}

JC, KC, and LE wrote and edited the manuscript. All authors contributed to the article and approved the submitted version.

\section{FUNDING}

This manuscript was funded by National Institutes of Health Grants R21 AI124490 and R21 AI152447 to LE.

\section{ACKNOWLEDGMENTS}

We thank Drs. Thomas A. E. Platts-Mills and Jeffrey M. Wilson (University of Virginia School of Medicine, Charlottesville, VA) for critically reading the manuscript.

4. Commins SP, Kelly LA, Ronmark E, James HR, Pochan SL, Peters EJ, et al. Galactose-alpha-1,3-galactose-specific IgE is associated with anaphylaxis but not asthma. Am J Respir Crit Care Med. (2012) 185:72330. doi: 10.1164/rccm.201111-2017OC

5. Hamsten C, Tran TA, Starkhammar M, Brauner A, Commins SP, Platts-Mills TA, et al. Red meat allergy in Sweden: association with tick sensitization and B-negative blood groups. J Allergy Clin Immunol. (2013) 132:14314. doi: 10.1016/j.jaci.2013.07.050

6. Caponetto P, Fischer J, Biedermann T. Gelatin-containing sweets can elicit anaphylaxis in a patient with sensitization to galactose-alpha-1,3-galactose. $J$ Allergy Clin Immunol Pract. (2013) 1:302-3. doi: 10.1016/j.jaip.2013.01.007

7. Morisset M, Richard C, Astier C, Jacquenet S, Croizier A, Beaudouin E, et al. Anaphylaxis to pork kidney is related to $\operatorname{IgE}$ 
antibodies specific for galactose-alpha-1,3-galactose. Allergy. 67:699-704. doi: 10.1111/j.1398-9995.2012.02799.x

8. Sekiya K, Fukutomi Y, Nakazawa T, Taniguchi M, Akiyama K. Delayed anaphylactic reaction to mammalian meat. J Investig Allergol Clin Immunol. (2012) 22:446-7.

9. Nunez R, Carballada F, Gonzalez-Quintela A, Gomez-Rial J, Boquete M, Vidal C. Delayed mammalian meat-induced anaphylaxis due to galactosealpha-1,3-galactose in 5 European patients. J Allergy Clin Immunol. (2011) 128:1122-4. doi: 10.1016/j.jaci.2011.07.020

10. Chung CH, Mirakhur B, Chan E, Le QT, Berlin J, Morse M, et al. Cetuximabinduced anaphylaxis and IgE specific for galactose-alpha-1,3-galactose. $\mathrm{N}$ Engl J Med. (2008) 358:1109-17. doi: 10.1056/NEJMoa074943

11. Wilson JM, Platts-Mills TAE. Meat allergy and allergens. Mol Immunol. (2018) 100:107-12. doi: 10.1016/j.molimm.2018.03.018

12. Commins SP, Jerath MR, Cox K, Erickson LD, Platts-Mills T. Delayed anaphylaxis to alpha-gal, an oligosaccharide in mammalian meat. Allergol Int. (2016) 65:16-20. doi: 10.1016/j.alit.2015.10.001

13. Commins SP, James HR, Stevens W, Pochan SL, Land MH, King C, et al. Delayed clinical and ex vivo response to mammalian meat in patients with IgE to galactose-alpha-1,3-galactose. J Allergy Clin Immunol. (2014) 134:108-15. doi: 10.1016/j.jaci.2014.01.024

14. O'Neil BH, Allen R, Spigel DR, Stinchcombe TE, Moore DT, Berlin JD, et al. High incidence of cetuximab-related infusion reactions in Tennessee and North Carolina and the association with atopic history. J Clin Oncol. (2007) 25:3644-8. doi: 10.1200/JCO.2007.11.7812

15. Qian J, Liu T, Yang L, Daus A, Crowley R, Zhou Q. Structural characterization of $\mathrm{N}$-linked oligosaccharides on monoclonal antibody cetuximab by the combination of orthogonal matrix-assisted laser desorption/ionization hybrid quadrupole-quadrupole time-of-flight tandem mass spectrometry and sequential enzymatic digestion. Anal Biochem. (2007) 364:8-18. doi: 10.1016/j.ab.2007.01.023

16. Dahlgren FS, Paddock CD, Springer YP, Eisen RJ, Behravesh CB. Expanding range of Amblyomma americanum and simultaneous changes in the epidemiology of Spotted Fever Group Rickettsiosis in the United States. Am J Trop Med Hyg. (2016) 94:35-42. doi: 10.4269/ajtmh.15-0580

17. Paddock CD, Yabsley MJ. Ecological havoc, the rise of white-tailed deer, and the emergence of Amblyomma americanum-associated zoonoses in the United States. Curr Top Microbiol Immunol. (2007) 315:289324. doi: 10.1007/978-3-540-70962-6_12

18. Centers for Disease Control and Prevention. Approximate Distribution of the Lone Star Tick. (2011). Available online at: http://www.cdc.gov/ticks/maps/ lone_star_tick.html (accessed July 05, 2020).

19. Jaworski DC, Bowen CJ, Wasala NB. A white-tailed deer/lone star tick model for studying transmission of Ehrlichia chaffeensis. Vector Borne Zoonotic Dis. (2013) 13:193-5. doi: 10.1089/vbz.2011.0868

20. Kwak M, Somerville C, van Nunen S. A novel Australian tick Ixodes (Endopalpiger) australiensis inducing mammalian meat allergy after tick bite. Asia Pac Allergy. (2018) 8:e31. doi: 10.5415/apallergy.2018.8.e31

21. Mabelane T, Basera W, Botha M, Thomas HF, Ramjith J, Levin ME. Predictive values of alpha-gal IgE levels and alpha-gal IgE: total IgE ratio and oral food challenge-proven meat allergy in a population with a high prevalence of reported red meat allergy. Pediatr Allergy Immunol. (2018) 29:841-9. doi: 10.1111/pai.12969

22. Cunningham D, Humblet Y, Siena S, Khayat D, Bleiberg H, Santoro A, et al. Cetuximab monotherapy and cetuximab plus irinotecan in irinotecanrefractory metastatic colorectal cancer. N Engl J Med. (2004) 351:33745. doi: 10.1056/NEJMoa033025

23. Saltz LB, Lenz HJ, Kindler HL, Hochster HS, Wadler S, Hoff PM, et al. Randomized phase II trial of cetuximab, bevacizumab, and irinotecan compared with cetuximab and bevacizumab alone in irinotecan-refractory colorectal cancer: the BOND-2 study. J Clin Oncol. (2007) 25:455761. doi: 10.1200/JCO.2007.12.0949

24. Platts-Mills TAE, Li RC, Keshavarz B, Smith AR, Wilson JM. Diagnosis and management of patients with the alpha-gal syndrome. J Allergy Clin Immunol Pract. (2019) 8:15-23. doi: 10.1016/j.jaip.2019.09.017

25. Cabezas-Cruz A, Hodzic A, Roman-Carrasco P, Mateos-Hernandez L, Duscher GG, Sinha DK, et al. Environmental and molecular drivers of the alpha-gal syndrome. Front Immunol.

(2019) 10:1210. doi: 10.3389/fimmu.2019.01210

26. Steinke JW, Platts-Mills TA, Commins SP. The alpha-gal story: lessons learned from connecting the dots. J Allergy Clin Immunol. (2015) 135:58996. doi: 10.1016/j.jaci.2014.12.1947

27. Kim MS, Straesser MD, Keshavarz B, Workman L, McGowan EC, PlattsMills TAE, et al. IgE to galactose-alpha-1,3-galactose wanes over time in patients who avoid tick bites. J Allergy Clin Immunol Pract. (2020) 8:3647. doi: $10.1016 /$ j.jaip.2019.08.045

28. van Nunen S. Tick-induced allergies: mammalian meat allergy, tick anaphylaxis and their significance. Asia Pac Allergy. (2015) 5:3-16. doi: 10.5415/apallergy.2015.5.1.3

29. Araujo RN, Franco PF, Rodrigues H, Santos LC, McKay CS, Sanhueza CA, et al. Amblyomma sculptum tick saliva: alpha-gal identification, antibody response and possible association with red meat allergy in Brazil. Int $J$ Parasitol. (2016) 46:213-20. doi: 10.1016/j.ijpara.2015.12.005

30. Jacquenet S, Moneret-Vautrin DA, Bihain BE. Mammalian meat-induced anaphylaxis: clinical relevance of anti-galactose-alpha-1,3-galactose $\operatorname{IgE}$ confirmed by means of skin tests to cetuximab. J Allergy Clin Immunol. (2009) 124:603-5. doi: 10.1016/j.jaci.2009.06.014

31. Hodzic A, Mateos-Hernandez L, de la Fuente J, Cabezas-Cruz A. Delayed hypersensitivity reaction to mammalian galactose-alpha-1,3galactose (alpha-Gal) after repeated tick bites in a patient from France. Ticks Tick Borne Dis. (2019) 10:1057-9. doi: 10.1016/j.ttbdis.2019.05.017

32. Hamsten C, Starkhammar M, Tran TA, Johansson M, Bengtsson U, Ahlen $\mathrm{G}$, et al. Identification of galactose-alpha-1,3-galactose in the gastrointestinal tract of the tick Ixodes ricinus; possible relationship with red meat allergy. Allergy. (2013) 68:549-52. doi: 10.1111/all.12128

33. Chinuki Y, Ishiwata K, Yamaji K, Takahashi H, Morita E. Haemaphysalis longicornis tick bites are a possible cause of red meat allergy in Japan. Allergy. (2016) 71:421-5. doi: 10.1111/all.12804

34. Gonzalez-Quintela A, Dam Laursen AS, Vidal C, Skaaby T, Gude F, Linneberg A. IgE antibodies to alpha-gal in the general adult population: relationship with tick bites, atopy, and cat ownership. Clin Exp Allergy. (2014) 44:1061-8. doi: 10.1111/cea.12326

35. Fischer J, Lupberger E, Hebsaker J, Blumenstock G, Aichinger E, Yazdi AS, et al. Prevalence of type I sensitization to alpha-gal in forest service employees and hunters. Allergy. (2017) 72:1540-7. doi: 10.1111/all. 13156

36. Mehlich J, Fischer J, Hilger C, Swiontek K, Morisset M, Codreanu-Morel $\mathrm{F}$, et al. The basophil activation test differentiates between patients with alpha-gal syndrome and asymptomatic alpha-gal sensitization. J Allergy Clin Immunol. (2019) 143:182-9. doi: 10.1016/j.jaci.2018.06.049

37. Cooper DK. Depletion of natural antibodies in non-human primates-a step towards successful discordant xenografting in humans. Clin Transplant. (1992) 6(3 part 1):178-83.

38. Cooper DK, Good AH, Koren E, Oriol R, Malcolm AJ, Ippolito $\mathrm{RM}$, et al. Identification of alpha-galactosyl and other carbohydrate epitopes that are bound by human anti-pig antibodies: relevance to discordant xenografting in man. Transpl Immunol. (1993) 1:198205. doi: 10.1016/0966-3274(93)90047-C

39. Cooper DK, Koren E, Oriol R. Oligosaccharides and discordant xenotransplantation. Immunol Rev. (1994) 141:3158. doi: 10.1111/j.1600-065X.1994.tb00871.x

40. Good AH, Cooper DK, Malcolm AJ, Ippolito RM, Koren E, Neethling FA, et al. Identification of carbohydrate structures that bind human antiporcine antibodies: implications for discordant xenografting in humans. Transplant Proc. (1992) 24:559-62.

41. Kobayashi T, Cooper DK. Anti-Gal, alpha-Gal epitopes, and xenotransplantation. Subcell Biochem. (1999) 32:22957. doi: 10.1007/978-1-4615-4771-6_10

42. Basu M, Basu S. Enzymatic synthesis of a blood group B-related pentaglycosylceramide by an alpha-galactosyltransferase from rabbit bone marrow. J Biol Chem. (1973) 248:1700-6.

43. Galili U, Rachmilewitz EA, Peleg A, Flechner I. A unique natural human IgG antibody with anti-alpha-galactosyl specificity. J Exp Med. (1984) 160:151931. doi: $10.1084 /$ jem.160.5.1519 
44. Galili U, Shohet SB, Kobrin E, Stults CL, Macher BA. Man, apes, and Old World monkeys differ from other mammals in the expression of alphagalactosyl epitopes on nucleated cells. J Biol Chem. (1988) 263:17755-62.

45. Galili U, Mandrell RE, Hamadeh RM, Shohet SB, Griffiss JM. Interaction between human natural anti-alpha-galactosyl immunoglobulin $\mathrm{G}$ and bacteria of the human flora. Infect Immun. (1988) 56:1730-7. doi: 10.1128/IAI.56.7.1730-1737.1988

46. Galili U. The alpha-gal epitope and the anti-Gal antibody in xenotransplantation and in cancer immunotherapy. Immunol Cell Biol. (2005) 83:674-86. doi: 10.1111/j.1440-1711.2005.01366.x

47. Tseng YL, Kuwaki K, Dor FJ, Shimizu A, Houser S, Hisashi Y, et al. alpha1,3-galactosyltransferase gene-knockout pig heart transplantation in baboons with survival approaching 6 months. Transpl. (2005) 80:1493500. doi: 10.1097/01.tp.0000181397.41143.fa

48. Yamada K, Yazawa K, Shimizu A, Iwanaga T, Hisashi Y, Nuhn M, et al. Marked prolongation of porcine renal xenograft survival in baboons through the use of alpha1,3-galactosyltransferase gene-knockout donors and the cotransplantation of vascularized thymic tissue. Nat Med. (2005) 11:324. doi: $10.1038 / \mathrm{nm} 1172$

49. Hisashi Y, Yamada K, Kuwaki K, Tseng YL, Dor FJ, Houser SL, et al. Rejection of cardiac xenografts transplanted from alpha1,3-galactosyltransferase geneknockout (GalT-KO) pigs to baboons. Am J Transplant. (2008) 8:251626. doi: 10.1111/j.1600-6143.2008.02444.x

50. Rood PP, Tai HC, Hara H, Long C, Ezzelarab M, Lin YJ, et al. Late onset of development of natural anti-nonGal antibodies in infant humans and baboons: implications for xenotransplantation in infants. Transpl Int. (2007) 20:1050-8. doi: 10.1111/j.1432-2277.2007.00546.x

51. Minanov OP, Itescu S, Neethling FA, Morgenthau AS, Kwiatkowski P, Cooper DK, et al. Anti-gal IgG antibodies in sera of newborn humans and baboons and its significance in pig xenotransplantation. Transpl. (1997) 63:182-6. doi: 10.1097/00007890-199701270-00002

52. Montassier E, Al-Ghalith GA, Mathe C, Le Bastard Q, Douillard V, Garnier A, et al. Distribution of bacterial alpha1,3-galactosyltransferase genes in the human gut microbiome. Front Immunol. (2019) 10:3000. doi: 10.3389/fimmu.2019.03000

53. Yilmaz B, Portugal S, Tran TM, Gozzelino R, Ramos S, Gomes J, et al. Gut microbiota elicits a protective immune response against malaria transmission. Cell. (2014) 159:1277-89. doi: 10.1016/j.cell.2014.10.053

54. Portillo S, Zepeda BG, Iniguez E, Olivas JJ, Karimi NH, Moreira OC, et al. A prophylactic alpha-Gal-based glycovaccine effectively protects against murine acute Chagas disease. NPJ Vaccines. (2019) 4:13. doi: 10.1038/s41541-019-0107-7

55. Moura APV, Santos LCB, Brito CRN, Valencia E, Junqueira C, Filho AAP, et al. Virus-like particle display of the alpha-gal carbohydrate for vaccination against Leishmania infection. ACS Cent Sci. (2017) 3:102631. doi: 10.1021/acscentsci.7b00311

56. Iniguez E, Schocker NS, Subramaniam K, Portillo S, Montoya AL, Al-Salem WS, et al. An alpha-gal-containing neoglycoprotein-based vaccine partially protects against murine cutaneous leishmaniasis caused by Leishmania major. PLoS Negl Trop Dis. (2017) 11:e0006039. doi: 10.1371/journal.pntd.0006039

57. Pacheco I, Contreras M, Villar M, Risalde MA, Alberdi P, CabezasCruz A, et al. Vaccination with alpha-gal protects against mycobacterial infection in the zebrafish model of tuberculosis. Vaccines. (2020) 8:e195. doi: 10.3390/vaccines8020195

58. Cabezas-Cruz A, Mateos-Hernandez L, Alberdi P, Villar M, Riveau G, Hermann E, et al. Effect of blood type on anti-alpha-gal immunity and the incidence of infectious diseases. Exp Mol Med. (2017) 49:e301. doi: 10.1038/emm.2016.164

59. Hodzic A, Mateos-Hernandez L, Frealle E, Roman-Carrasco P, Alberdi $\mathrm{P}$, Pichavant $\mathrm{M}$, et al. Infection with Toxocara canis inhibits the production of $\mathrm{IgE}$ antibodies to alpha-gal in humans: towards a conceptual framework of the hygiene hypothesis? Vaccines. (2020) 8:e167. doi: 10.3390/vaccines8020167

60. Hodzic A, Mateos-Hernandez L, Leschnik M, Alberdi P, Rego ROM, Contreras $\mathrm{M}$, et al. Tick bites induce anti-alpha-gal antibodies in dogs. Vaccines. (2019) 7:114. doi: 10.3390/vaccines7030114
61. Cabezas-Cruz A, Espinosa PJ, Alberdi P, Simo L, Valdes JJ, MateosHernandez L, et al. Tick galactosyltransferases are involved in alphagal synthesis and play a role during Anaplasma phagocytophilum infection and Ixodes scapularis tick vector development. Sci Rep. (2018) 8:14224. doi: 10.1038/s41598-018-32664-Z

62. Villar M, Pacheco I, Merino O, Contreras M, Mateos-Hernandez L, Prado E, et al. Tick and host derived compounds detected in the cement complex substance. Biomolecules. (2020) 10:555. doi: 10.3390/biom 10040555

63. Crispell G, Commins SP, Archer-Hartman SA, Choudhary S, Dharmarajan G, Azadi P, et al. Discovery of alpha-gal-containing antigens in North American tick species believed to induce red meat allergy. Front Immunol. (2019) 10:1056. doi: 10.3389/fimmu.2019.01056

64. Park Y, Kim D, Boorgula GD, De Schutter K, Smagghe G, Simo L, et al. Alpha-gal and cross-reactive carbohydrate determinants in the N-glycans of salivary glands in the Lone Star Tick, Amblyomma americanum. Vaccines. (2020) 8:18. doi: 10.3390/vaccines 8010018

65. Maeda K, Caldez MJ, Akira S. Innate immunity in allergy. Allergy. (2019) 74:1660-74. doi: 10.1111/all.13788

66. Morita H, Moro K, Koyasu S. Innate lymphoid cells in allergic and nonallergic inflammation. J Allergy Clin Immunol. (2016) 138:125364. doi: 10.1016/j.jaci.2016.09.011

67. Eisenbarth SC. Dendritic cell subsets in $\mathrm{T}$ cell programming: location dictates function. Nat Rev Immunol. (2019) 19:89103. doi: 10.1038/s41577-018-0088-1

68. Mowat AM. Anatomical basis of tolerance and immunity to intestinal antigens. Nat Rev Immunol. (2003) 3:331-41. doi: 10.1038/nri1057

69. Rescigno M, Urbano M, Valzasina B, Francolini M, Rotta G, Bonasio R, et al. Dendritic cells express tight junction proteins and penetrate gut epithelial monolayers to sample bacteria. Nat Immunol. (2001) 2:3617. doi: $10.1038 / 86373$

70. Soumelis V, Reche PA, Kanzler H, Yuan W, Edward G, Homey B, et al. Human epithelial cells trigger dendritic cell mediated allergic inflammation by producing TSLP. Nat Immunol. (2002) 3:673-80. doi: 10.1038/ni805

71. Ito T, Carson WFt, Cavassani KA, Connett JM, Kunkel SL. CCR6 as a mediator of immunity in the lung and gut. Exp Cell Res. (2011) 317:6139. doi: 10.1016/j.yexcr.2010.12.018

72. Shimoda K, van Deursen J, Sangster MY, Sarawar SR, Carson RT, Tripp RA, et al. Lack of IL-4-induced Th2 response and IgE class switching in mice with disrupted Stat6 gene. Nature. (1996) 380:630-3. doi: 10.1038/380630a0

73. Takeda K, Tanaka T, Shi W, Matsumoto M, Minami M, Kashiwamura S, et al. Essential role of Stat6 in IL-4 signalling. Nature. (1996) 380:62730. doi: 10.1038/380627a0

74. Zhu J, Min B, Hu-Li J, Watson CJ, Grinberg A, Wang Q, et al. Conditional deletion of Gata3 shows its essential function in $\mathrm{T}(\mathrm{H}) 1-\mathrm{T}(\mathrm{H}) 2$ responses. Nat Immunol. (2004) 5:1157-65. doi: 10.1038/ni1128

75. Kobayashi T, Iijima K, Dent AL, Kita H. Follicular helper T cells mediate IgE antibody response to airborne allergens. J Allergy Clin Immunol. (2017) 139:300-13. doi: 10.1016/j.jaci.2016.04.021

76. Meli AP, Fontes G, Leung Soo C, King IL. T follicular helper cell-derived IL-4 is required for IgE production during intestinal helminth infection. J Immunol. (2017) 199:244-52. doi: 10.4049/jimmunol. 1700141

77. Noble A, Zhao J. Follicular helper T cells are responsible for IgE responses to Der p 1 following house dust mite sensitization in mice. Clin Exp Allergy. (2016) 46:1075-82. doi: 10.1111/cea.12750

78. Dolence JJ, Kobayashi T, Iijima K, Krempski J, Drake LY, Dent AL, et al. Airway exposure initiates peanut allergy by involving the IL-1 pathway and $\mathrm{T}$ follicular helper cells in mice. J Allergy Clin Immunol. (2018) 142:114458. doi: 10.1016/j.jaci.2017.11.020

79. Liang HE, Reinhardt RL, Bando JK, Sullivan BM, Ho IC, Locksley RM. Divergent expression patterns of IL-4 and IL-13 define unique functions in allergic immunity. Nat Immunol. (2011) 13:58-66. doi: 10.1038/ni.2182

80. Morita R, Schmitt N, Bentebibel SE, Ranganathan R, Bourdery L, Zurawski G, et al. Human blood CXCR5 $(+) \operatorname{CD} 4(+) \mathrm{T}$ cells are counterparts of $\mathrm{T}$ follicular cells and contain specific subsets that differentially support antibody secretion. Immunity. (2011) 34:10821. doi: 10.1016/j.immuni.2010.12.012 
81. Gowthaman U, Chen JS, Zhang B, Flynn WF, Lu Y, Song W, et al. Identification of a $\mathrm{T}$ follicular helper cell subset that drives anaphylactic IgE. Science. (2019) 365:1-14. doi: 10.1126/science.aaw6433

82. Cabezas-Cruz A, Valdes JJ. Are ticks venomous animals? Front Zool. (2014) 11:47. doi: 10.1186/1742-9994-11-47

83. Ferreira BR, Silva JS. Successive tick infestations selectively promote a T-helper 2 cytokine profile in mice. Immunology. (1999) 96:4349. doi: 10.1046/j.1365-2567.1999.00683.x

84. Schoeler GB, Manweiler SA, Wikel SK. Ixodes scapularis: Effects of repeated infestations with pathogen-free nymphs on macrophage and T lymphocyte cytokine responses of $\mathrm{BALB} / \mathrm{c}$ and $\mathrm{C} 3 \mathrm{H} / \mathrm{HeN}$ mice. Exp Parasitol. (1999) 92:239-48. doi: 10.1006/expr.1999.4426

85. Mejri N, Franscini N, Rutti B, Brossard M. Th2 polarization of the immune response of $\mathrm{BALB} / \mathrm{c}$ mice to Ixodes ricinus instars, importance of several antigens in activation of specific Th2 subpopulations. Parasite Immunol. (2001) 23:61-9. doi: 10.1046/j.1365-3024.2001.00356.x

86. Kovar L, Kopecky J, Rihova B. Salivary gland extract from Ixodes ricinus tick polarizes the cytokine profile toward $\mathrm{TH} 2$ and suppresses proliferation of T lymphocytes in human PBMC culture. J Parasitol. (2001) 87:13428. doi: $10.2307 / 3285298$

87. Müller-Doblies UU, Maxwell SS, Boppana VD, Mihalyo MA, McSorley SJ, Vella AT, et al. Feeding by the tick, Ixodes scapularis, causes CD4+ $\mathrm{T}$ cells responding to cognate antigen to develop the capacity to express IL-4. Parasite Immunol. (2007) 29:485-99. doi: 10.1111/j.1365-3024.2007. 00966.x

88. Mejri N, Brossard M. Splenic dendritic cells pulsed with Ixodes ricinus tick saliva prime naive CD4+T to induce Th2 cell differentiation in vitro and in vivo. Int Immunol. (2007) 19:535-43. doi: 10.1093/intimm/dxm019

89. Skallová A, Iezzi G, Ampenberger F, Kopf M, Kopecký J. Tick saliva inhibits dendritic cell migration, maturation, and function while promoting development of Th2 responses. J Immunol. (2008) 180:6186-92. doi: 10.4049/jimmunol.180.9.6186

90. Oliveira CJ, Sa-Nunes A, Francischetti IM, Carregaro V, Anatriello E, Silva JS, et al. Deconstructing tick saliva: non-protein molecules with potent immunomodulatory properties. J Biol Chem. (2011) 286:109609. doi: 10.1074/jbc.M110.205047

91. Carvalho-Costa TM, Mendes MT, da Silva MV, da Costa TA, Tiburcio $\mathrm{MG}$, Anhe AC, et al. Immunosuppressive effects of Amblyomma cajennense tick saliva on murine bone marrow-derived dendritic cells. Parasit Vectors. (2015) 8:22. doi: 10.1186/s13071-015-0634-7

92. Alarcon-Chaidez FJ, Boppana VD, Hagymasi AT, Adler AJ, Wikel SK. A novel sphingomyelinase-like enzyme in Ixodes scapularis tick saliva drives host CD4+ T cells to express IL-4. Parasite Immunol. (2009) 31:2109. doi: 10.1111/j.1365-3024.2009.01095.x

93. Lieskovska J, Palenikova J, Sirmarova J, Elsterova J, Kotsyfakis M, Campos Chagas A, et al. Tick salivary cystatin sialostatin L2 suppresses IFN responses in mouse dendritic cells. Parasite Immunol. (2015) 37:708. doi: $10.1111 /$ pim. 12162

94. Li H, Edin ML, Gruzdev A, Cheng J, Bradbury JA, Graves JP, et al. Regulation of $\mathrm{T}$ helper cell subsets by cyclooxygenases and their metabolites. Prostaglandins Other Lipid Mediat. (2013) 104-105:7483. doi: 10.1016/j.prostaglandins.2012.11.002

95. Gao Y, Zhao C, Wang W, Jin R, Li Q, Ge Q, et al. Prostaglandins E2 signal mediated by receptor subtype EP2 promotes IgE production in vivo and contributes to asthma development. Sci Rep. (2016) 6:20505. doi: 10.1038/srep20505

96. Fedyk ER, Phipps RP. Prostaglandin E2 receptors of the EP2 and EP4 subtypes regulate activation and differentiation of mouse B lymphocytes to IgE-secreting cells. Proc Natl Acad Sci USA. (1996) 93:1097883. doi: $10.1073 /$ pnas.93.20.10978

97. Roper RL, Brown DM, Phipps RP. Prostaglandin E2 promotes B lymphocyte Ig isotype switching to IgE. J Immunol. (1995) 154:162-70.

98. Roper RL, Conrad DH, Brown DM, Warner GL, Phipps RP. Prostaglandin E2 promotes IL-4-induced IgE and IgG1 synthesis. J Immunol. (1990) 145:2644-51.

99. Roper RL, Phipps RP. Prostaglandin E2 and cAMP inhibit B lymphocyte activation and simultaneously promote IgE and IgG1 synthesis. J Immunol. (1992) 149:2984-91.
100. Heinze DM, Wikel SK, Thangamani S, Alarcon-Chaidez FJ. Transcriptional profiling of the murine cutaneous response during initial and subsequent infestations with Ixodes scapularis nymphs. Parasit Vectors. (2012) 5:26. doi: 10.1186/1756-3305-5-26

101. Oliveira CJF, Cavassani KA, Moré DD, Garlet GP, Aliberti JC, Silva JS, et al. Tick saliva inhibits the chemotactic function of MIP- $1 \alpha$ and selectively impairs chemotaxis of immature dendritic cells by down-regulating cell-surface CCR5. Int J Parasitol. (2008) 38:70516. doi: 10.1016/j.ijpara.2007.10.006

102. Chmelar J, Anderson JM, Mu J, Jochim RC, Valenzuela JG, Kopecký J. Insight into the sialome of the castor bean tick, Ixodes ricinus. BMC Genom. (2008) 9:233. doi: 10.1186/1471-2164-9-233

103. McSwain JL, Essenberg RC, Sauer JR. Protein changes in the salivary glands of the female Lone Star Tick, Amblyomma americanum, during feeding. $J$ Parasitol. (1982) 68:100-6. doi: 10.2307/3281330

104. Perner J, Kropáčková S, Kopáček P, Ribeiro JMC. Sialome diversity of ticks revealed by RNAseq of single tick salivary glands. PLoS Negl Trop Dis. (2018) 12:e0006410. doi: 10.1371/journal.pntd.0006410

105. Ribeiro JMC, Alarcon-Chaidez F, Francischetti IMB, Mans BJ, Mather TN, Valenzuela JG, et al. An annotated catalog of salivary gland transcripts from Ixodes scapularis ticks. Insect Biochem Mol Biol. (2006) 36:11129. doi: 10.1016/j.ibmb.2005.11.005

106. Apostolovic D, Rodrigues R, Thomas P, Starkhammar M, Hamsten C, van Hage M. Immunoprofile of $\alpha$-Gal- and B-antigen-specific responses differentiates red meat-allergic patients from healthy individuals. Allergy Eur J Allergy Clin Immunol. (2018) 73:1525-31. doi: 10.1111/all.13400

107. Cabezas-Cruz A, Mateos-Hernandez L, Chmelar J, Villar M, de la Fuente J. Salivary prostaglandin E2: role in tick-induced allergy to red meat. Trends Parasitol. (2017) 33:495-8. doi: 10.1016/j.pt.2017.03.004

108. Talay O, Yan D, Brightbill HD, Straney EE, Zhou M, Ladi E, et al. $\operatorname{IgE}(+)$ memory B cells and plasma cells generated through a germinal-center pathway. Nat Immunol. (2012) 13:396-404. doi: 10.1038/ni.2256

109. Xiong H, Dolpady J, Wabl M, Curotto de Lafaille MA, Lafaille JJ. Sequential class switching is required for the generation of high affinity IgE antibodies. J Exp Med. (2012) 209:353-64. doi: 10.1084/jem.20111941

110. Erazo A, Kutchukhidze N, Leung M, Christ AP, Urban JF, Jr., et al. Unique maturation program of the IgE response in vivo. Immunity. (2007) 26:191203. doi: 10.1016/j.immuni.2006.12.006

111. Berkowska MA, Heeringa JJ, Hajdarbegovic E, van der Burg M, Thio HB, van Hagen PM, et al. Human $\operatorname{IgE}(+)$ B cells are derived from T celldependent and T cell-independent pathways. J Allergy Clin Immunol. (2014) 134:688-97. doi: 10.1016/j.jaci.2014.03.036

112. Jimenez-Saiz R, Bruton K, Koenig JFE, Waserman S, Jordana M. The IgE memory reservoir in food allergy. J Allergy Clin Immunol. (2018) 142:14413. doi: 10.1016/j.jaci.2018.08.029

113. Heeringa JJ, Rijvers L, Arends NJ, Driessen GJ, Pasmans SG, van Dongen JJM, et al. IgE-expressing memory B cells and plasmablasts are increased in blood of children with asthma, food allergy, and atopic dermatitis. Allergy. (2018) 73:1331-6. doi: 10.1111/all.13421

114. Jimenez-Saiz R, Ellenbogen Y, Bruton K, Spill P, Sommer DD, Lima H, et al. Human BCR analysis of single-sorted, putative $\operatorname{IgE}(+)$ memory B cells in food allergy. J Allergy Clin Immunol. (2019) 144:3369. doi: 10.1016/j.jaci.2019.04.001

115. Davies JM, Platts-Mills TA, Aalberse RC. The enigma of IgE+ B-cell memory in human subjects. J Allergy Clin Immunol. (2013) 131:9726. doi: 10.1016/j.jaci.2012.12.1569

116. He JS, Subramaniam S, Narang V, Srinivasan K, Saunders SP, Carbajo D, et al. IgG1 memory B cells keep the memory of IgE responses. Nat Comm. (2017) 8:641. doi: 10.1038/s41467-017-00723-0

117. Looney TJ, Lee JY, Roskin KM, Hoh RA, King J, Glanville J, et al. Human B-cell isotype switching origins of IgE. J Allergy Clin Immunol. (2016) 137:579-86. doi: 10.1016/j.jaci.2015.07.014

118. Mills FC, Mitchell MP, Harindranath N, Max EE. Human Ig S gamma regions and their participation in sequential switching to IgE. J Immunol. (1995) 155:3021-36.

119. Cameron L, Gounni AS, Frenkiel S, Lavigne F, Vercelli D, Hamid Q. $S$ epsilon $S \mathrm{mu}$ and $\mathrm{S}$ epsilon $\mathrm{S}$ gamma switch circles in human nasal mucosa following ex vivo allergen challenge: evidence for direct as well 
as sequential class switch recombination. J Immunol. (2003) 171:381622. doi: 10.4049/jimmunol.171.7.3816

120. Jabara HH, Loh R, Ramesh N, Vercelli D, Geha RS. Sequential switching from mu to epsilon via gamma 4 in human B cells stimulated with IL-4 and hydrocortisone. J Immunol. (1993) 151:4528-33.

121. Svirshchevskaya E, Fattakhova G, Khlgatian S, Chudakov D, Kashirina E, Ryazantsev D, et al. Direct versus sequential immunoglobulin switch in allergy and antiviral responses. Clin Immunol. (2016) 170:31-8. doi: 10.1016/j.clim.2016.07.022

122. Klein U, Kuppers R, Rajewsky K. Evidence for a large compartment of IgM-expressing memory B cells in humans. Blood. (1997) 89:128898. doi: 10.1182/blood.V89.4.1288

123. Klein U, Rajewsky K, Kuppers R. Human immunoglobulin (Ig)M+IgD+ peripheral blood B cells expressing the CD27 cell surface antigen carry somatically mutated variable region genes: $\mathrm{CD} 27$ as a general marker for somatically mutated (memory) B cells. J Exp Med. (1998) 188:167989. doi: $10.1084 /$ jem.188.9.1679

124. Tangye SG, Liu YJ, Aversa G, Phillips JH, de Vries JE. Identification of functional human splenic memory B cells by expression of CD148 and CD27. J Exp Med. (1998) 188:1691-703. doi: 10.1084/jem.188.9.1691

125. Richards SJ, Morgan GJ, Hillmen P. Immunophenotypic analysis of B cells in PNH: insights into the generation of circulating naive and memory B cells. Blood. (2000) 96:3522-8. doi: 10.1182/blood.V96.10.3522

126. Agematsu K, Nagumo H, Yang FC, Nakazawa T, Fukushima K, Ito S, et al. B cell subpopulations separated by CD27 and crucial collaboration of CD27+ $\mathrm{B}$ cells and helper $\mathrm{T}$ cells in immunoglobulin production. Eur J Immunol. (1997) 27:2073-9. doi: 10.1002/eji.1830270835

127. Shi Y, Agematsu K, Ochs HD, Sugane K. Functional analysis of human memory B-cell subpopulations: $\operatorname{IgD}+\mathrm{CD} 27+\mathrm{B}$ cells are crucial in secondary immune response by producing high affinity IgM. Clin Immunol. (2003) 108:128-37. doi: 10.1016/S1521-6616(03)00092-5

128. Jung S, Siebenkotten G, Radbruch A. Frequency of immunoglobulin E class switching is autonomously determined and independent of prior switching to other classes. J Exp Med. (1994) 179:2023-6. doi: 10.1084/jem.179.6.2023

129. Hoyer BF, Moser K, Hauser AE, Peddinghaus A, Voigt C, Eilat D, et al. Short-lived plasmablasts and long-lived plasma cells contribute to chronic humoral autoimmunity in NZB/W mice. J Exp Med. (2004) 199:157784. doi: $10.1084 /$ jem. 20040168

130. Manz RA, Radbruch A. Plasma cells for a lifetime? Eur J Immunol. (2002) 32:923-7. doi: 10.1002/1521-4141(200204)32:4<923::AID-IMMU923>3.0. $\mathrm{CO} ; 2-1$

131. Luger EO, Wegmann M, Achatz G, Worm M, Renz H, Radbruch A. Allergy for a lifetime? Allergol Int. (2010) 59:1-8. doi: 10.2332/allergolint.10-RAI-0175

132. Yoshida T, Mei H, Dorner T, Hiepe F, Radbruch A, Fillatreau S, et al. Memory B and memory plasma cells. Immunol Rev. (2010) 237:11739. doi: 10.1111/j.1600-065X.2010.00938.x

133. Asrat S, Kaur N, Liu X, Ben LH, Kajimura D, Murphy AJ, et al. Chronic allergen exposure drives accumulation of long-lived IgE plasma cells in the bone marrow, giving rise to serological memory. Sci Immunol. (2020) 5:eaav8402. doi: 10.1126/sciimmunol.aav8402

134. Yang Z, Sullivan BM, Allen CD. Fluorescent in vivo detection reveals that $\operatorname{IgE}(+) \mathrm{B}$ cells are restrained by an intrinsic cell fate predisposition. Immunity. (2012) 36:857-72. doi: 10.1016/j.immuni.2012.02.009

135. Walker SA, Riches PG, Wild G, Ward AM, Shaw PJ, Desai S, et al. Total and allergen-specific IgE in relation to allergic response pattern following bone marrow transplantation. Clin Exp Immunol. (1986) 66:633-9.

136. Tucker J, Barnetson RS, Eden OB. Atopy after bone marrow transplantation. Br Med J. (1985) 290:116-7. doi: 10.1136/bmj.290.6462.116

137. Storek J, Vliagoftis H, Grizel A, Lyon AW, Daly A, Khan F, et al. Allergy transfer with hematopoietic cell transplantation from an unrelated donor. Bone Marrow Transplant. (2011) 46:605-6. doi: 10.1038/bmt.2010.150

138. Wu LC, Scheerens H. Targeting IgE production in mice and humans. Curr Opin Immunol. (2014) 31:8-15. doi: 10.1016/j.coi.2014.08.001

139. Gauvreau GM, Harris JM, Boulet LP, Scheerens H, Fitzgerald JM, Putnam WS, et al. Targeting membrane-expressed IgE B cell receptor with an antibody to the M1 prime epitope reduces IgE production. Sci Transl Med. (2014) 6:243. doi: 10.1126/scitranslmed.3008961
140. Incorvaia C, Frati F, Verna N, D’Alo S, Motolese A, Pucci S. Allergy and the skin. Clin Exp Immunol. (2008) 153 (Suppl. 1):27-9. doi: 10.1111/j.1365-2249.2008.03718.x

141. Nicholson WL, Allen KE, McQuiston JH, Breitschwerdt EB, Little SE. The increasing recognition of rickettsial pathogens in dogs and people. Trends Parasitol. (2010) 26:205-12. doi: 10.1016/j.pt.2010.01.007

142. Brown SJ, Knapp FW. Response of hypersensitized guinea pigs to the feeding of Amblyomma americanum ticks. Parasitology. (1981) 83(Pt 1):21323. doi: $10.1017 / \mathrm{S} 0031182000050174$

143. Chandrasekhar JL, Cox KM, Loo WM, Qiao H, Tung KS, Erickson LD. Cutaneous exposure to clinically relevant Lone Star ticks promotes $\mathrm{IgE}$ production and hypersensitivity through $\mathrm{CD} 4(+) \mathrm{T}$ cell- and MyD88-dependent pathways in mice. I Immunol. (2019) 203:81324. doi: $10.4049 /$ jimmunol.1801156

144. Roman-Carrasco P, Lieder B, Somoza V, Ponce M, Szepfalusi Z, Martin D, et al. Only alpha-gal bound to lipids, but not to proteins, is transported across enterocytes as an IgE-reactive molecule that can induce effector cell activation. Allergy. (2019) 74:1956-68. doi: 10.1111/all.13873

145. Schnare M, Barton GM, Holt AC, Takeda K, Akira S, Medzhitov R. Toll-like receptors control activation of adaptive immune responses. Nat Immunol. (2001) 2:947-50. doi: 10.1038/ni712

146. Schroder NW. The role of innate immunity in the pathogenesis of asthma. Curr Opin Allergy Clin Immunol. (2009) 9:3843. doi: 10.1097/ACI.0b013e32831d0f99

147. Bezemer GF, Sagar S, van Bergenhenegouwen J, Georgiou NA, Garssen J, Kraneveld AD, et al. Dual role of Toll-like receptors in asthma and chronic obstructive pulmonary disease. Pharmacol Rev. (2012) 64:33758. doi: 10.1124/pr.111.004622

148. Matsushita K, Yoshimoto T. B cell-intrinsic MyD88 signaling is essential for IgE responses in lungs exposed to pollen allergens. J Immunol. (2014) 193:5791-800. doi: 10.4049/jimmunol.1401768

149. Tunis MC, Dawod B, Carson KR, Veinotte LL, Marshall JS. Toll-like receptor 2 activators modulate oral tolerance in mice. Clin Exp Allergy. (2015) 45:1690-702. doi: 10.1111/cea.12605

150. Berin MC, Wang W. Reduced severity of peanut-induced anaphylaxis in TLR9-deficient mice is associated with selective defects in humoral immunity. Mucosal Immunol. (2013) 6:114-21. doi: 10.1038/mi.2012.55

151. Bashir ME, Louie S, Shi HN, Nagler-Anderson C. Toll-like receptor 4 signaling by intestinal microbes influences susceptibility to food allergy. J Immunol. (2004) 172:6978-87. doi: 10.4049/jimmunol.172.11.6978

152. Monie TP, Bryant CE. Allergens and activation of the Tolllike receptor response. Methods Mol Biol. (2016) 1390:34150. doi: 10.1007/978-1-4939-3335-8_21

153. Liu CF, Drocourt D, Puzo G, Wang JY, Riviere M. Innate immune response of alveolar macrophage to house dust mite allergen is mediated through TLR2/-4 co-activation. PLoS ONE. (2013) 8:e75983. doi: 10.1371/journal.pone.0075983

154. Chiou YL, Lin CY. Der p2 activates airway smooth muscle cells in a TLR2/MyD88-dependent manner to induce an inflammatory response. J Cell Physiol. (2009) 220:311-8. doi: 10.1002/jcp.21764

155. Thomas WR, Hales BJ, Smith WA. Structural biology of allergens. Curr Allergy Asthma Rep. (2005) 5:388-93. doi: 10.1007/s11882-005-0012-1

156. Dinarello CA. Immunological and inflammatory functions of the interleukin-1 family. Annu Rev Immunol. (2009) 27:51950. doi: 10.1146/annurev.immunol.021908.132612

157. Contreras M, Pacheco I, Alberdi P, Díaz-Sánchez S, Artigas-Jerónimo S, Mateos-Hernández L, et al. Allergic reactions and immunity in response to tick salivary biogenic substances and red meat consumption in the zebrafish model. Front Cell Infect Microbiol. (2020) 10:78. doi: 10.3389/fcimb. 2020.00078

158. Šimo L, Kazimirova M, Richardson J, Bonnet SI. The essential role of tick salivary glands and saliva in tick feeding and pathogen transmission. Front Cell Infect Microbiol. (2017) 7:281. doi: 10.3389/fcimb.2017. 00281

159. Ribeiro JMC, Makoul GT, Levine J, Robinson DR, Spielman A. Antihemostatic, antiinflammatory, and immunosuppressive properties of the saliva of a tick, Ixodes dammini. J Exp Med. (1985) 161:332-44. doi: 10.1084/jem.161.2.332 
160. Ribeiro JMC, Evans PM, MacSwain JL, Sauer J. Amblyomma americanum: Characterization of salivary prostaglandins E2 and F2 $\alpha$ by RPHPLC/bioassay and gas chromatography-mass spectrometry. Exp Parasitol. (1992) 74:112-6. doi: 10.1016/0014-4894(92)90145-Z

161. Cheng Y, Wu H, Li D. An inhibitor selective for collagen-stimulated platelet aggregation from the salivary glands of hard tick Haemaphysalis longicornis and its mechanism of action. Sci China. (1999) 42:45764. doi: $10.1007 / \mathrm{BF} 02881768$

162. Aljamali M, Bowman AS, Dillwith JW, Tucker JS, Yates GW, Essenberg RC, et al. Identity and synthesis of prostaglandins in the lone star tick, Amblyomma americanum (L.), as assessed by radio-immunoassay and gas chromatography/mass spectrometry. Insect Biochem Mol Biol. (2002) 32:331-41. doi: 10.1016/S0965-1748(01)00113-8

163. Francischetti IMB, Valenzuela JG, Andersen JF, Mather TN, Ribeiro JMC. Ixolaris, a novel recombinant tissue factor pathway inhibitor (TFPI) from the salivary gland of the tick, Ixodes scapularis: Identification of factor $\mathrm{X}$ and factor Xa as scaffolds for the inhibition of factor VIIa/tissue factor complex. Blood. (2002) 99:3602-12. doi: 10.1182/blood-2001-12-0237

164. Francischetti IMB, Mather TN, Ribeiro JMC. Tick saliva is a potent inhibitor of endothelial cell proliferation and angiogenesis. Thromb Haemost. (2005) 94:167-74. doi: 10.1160/TH04-09-0566

165. Narasimhan S, Koski RA, Beaulieu B, Anderson JF, Ramamoorthi N, Kantor F, et al. A novel family of anticoagulants from the saliva of Ixodes scapularis. Insect Mol Biol. (2002) 11:641-50. doi: 10.1046/j.1365-2583.2002.00375.x

166. Paesen GC, Adams PL, Harlos K, Nuttall PA, Stuart DI. Tick histaminebinding proteins: isolation, cloning, and three-dimensional structure. Mol Cell. (1999) 3:661-71. doi: 10.1016/S1097-2765(00)80359-7

167. Beaufays J, Adam B, Menten-Dedoyart C, Fieves L, Grosjean A, Decrem Y, et al. Ir-LBP, an Ixodes ricinus tick salivary LTB4-binding lipocalin, interferes with host neutrophil function. PLOS ONE. (2008) 3:e3987. doi: 10.1371/journal.pone.0003987

168. Heinze DM, Carmical JR, Aronson JF, Thangamani S. Early immunologic events at the tick-host interface. PLoS ONE. (2012) 7:e47301. doi: 10.1371/journal.pone.0047301

169. Han H, Roan F, Ziegler SF. The atopic march: current insights into skin barrier dysfunction and epithelial cell-derived cytokines. Immunol Rev. (2017) 278:116-30. doi: 10.1111/imr.12546

170. Hill DJ, Hosking CS. Food allergy and atopic dermatitis in infancy: an epidemiologic study. Pediatr Allergy Immunol. (2004) 15:421-7. doi: 10.1111/j.1399-3038.2004.00178.x

171. Martin PE, Eckert JK, Koplin JJ, Lowe AJ, Gurrin LC, Dharmage SC, et al. Which infants with eczema are at risk of food allergy? Results from a population-based cohort. Clin Exp Allergy. (2015) 45:25564. doi: 10.1111/cea.12406

172. Czarnowicki T, Gonzalez J, Bonifacio KM, Shemer A, Xiangyu P, Kunjravia $\mathrm{N}$, et al. Diverse activation and differentiation of multiple B-cell subsets in patients with atopic dermatitis but not in patients with psoriasis. J Allergy Clin Immunol. (2016) 137:118-29. doi: 10.1016/j.jaci.2015.08.027

173. Mahmoud F, Abul H, al Saleh Q, Hassab-el Naby H, Kajeji M, Haines D, et al. Elevated B-lymphocyte levels in lesional tissue of non-arthritic psoriasis. $J$ Dermatol. (1999) 26:428-33. doi: 10.1111/j.1346-8138.1999.tb02021.x

174. Yuan H, Zhou S, Liu Z, Cong W, Fei X, Zeng W, et al. Pivotal role of lesional and perilesional T/B lymphocytes in pemphigus pathogenesis. $J$ Invest Dermatol. (2017) 137:2362-70. doi: 10.1016/j.jid.2017.05.032

175. Hussein MR, Aboulhagag NM, Atta HS, Atta SM. Evaluation of the profile of the immune cell infiltrate in lichen planus, discoid lupus erythematosus, and chronic dermatitis. Pathology. (2008) 40:68293. doi: 10.1080/00313020802320739

176. O'Brien JC, Hosler GA, Chong BF. Changes in T cell and B cell composition in discoid lupus erythematosus skin at different stages. J Dermatol Sci. (2017) 85:247-9. doi: 10.1016/j.jdermsci.2016.12.004

177. Kogame T, Yamashita R, Hirata M, Kataoka TR, Kamido H, Ueshima C, et al. Analysis of possible structures of inducible skin-associated lymphoid tissue in lupus erythematosus profundus. J Dermatol. (2018) 45:111721. doi: $10.1111 / 1346-8138.14498$

178. van Beek N, Schulze FS, Zillikens D, Schmidt E. IgE-mediated mechanisms in bullous pemphigoid and other autoimmune bullous diseases. Expert Rev Clin Immunol. (2016) 12:267-77. doi: 10.1586/1744666X.2016.1123092
179. Bosello S, Angelucci C, Lama G, Alivernini S, Proietti G, Tolusso B, et al. Characterization of inflammatory cell infiltrate of scleroderma skin: B cells and skin score progression. Arthritis Res Ther. (2018) 20:75. doi: 10.1186/s13075-018-1569-0

180. Shen P, Fillatreau S. Antibody-independent functions of B cells: a focus on cytokines. Nat Rev Immunol. (2015) 15:441-51. doi: 10.1038/nri3857

181. Ruddle NH. High endothelial venules and lymphatic vessels in tertiary lymphoid organs: characteristics, functions, and regulation. Front Immunol. (2016) 7:491. doi: 10.3389/fimmu.2016.00491

182. Geherin SA, Gomez D, Glabman RA, Ruthel G, Hamann A, Debes GF. IL$10+$ innate-like $B$ cells are part of the skin immune system and require alpha4betal integrin to migrate between the peritoneum and inflamed skin. J Immunol. (2016) 196:2514-25. doi: 10.4049/jimmunol.1403246

183. Yanaba K, Bouaziz JD, Haas KM, Poe JC, Fujimoto M, Tedder TF. A regulatory B cell subset with a unique CD1dhiCD5+ phenotype controls $\mathrm{T}$ cell-dependent inflammatory responses. Immunity. (2008) 28:63950. doi: 10.1016/j.immuni.2008.03.017

184. Yanaba K, Kamata M, Ishiura N, Shibata S, Asano Y, Tada Y, et al. Regulatory B cells suppress imiquimod-induced, psoriasis-like skin inflammation. $J$ Leukoc Biol. (2013) 94:563-73. doi: 10.1189/jlb.1112562

185. Kunkel EJ, Butcher EC. Plasma-cell homing. Nat Rev Immunol. (2003) 3:822-9. doi: 10.1038/nri1203

186. Liao F, Shirakawa AK, Foley JF, Rabin RL, Farber JM. Human B cells become highly responsive to macrophage-inflammatory protein-3 alpha/CC chemokine ligand-20 after cellular activation without changes in CCR6 expression or ligand binding. J Immunol. (2002) 168:487180. doi: 10.4049 /jimmunol.168.10.4871

187. Geherin SA, Fintushel SR, Lee MH, Wilson RP, Patel RT, Alt C, et al. The skin, a novel niche for recirculating B cells. J Immunol. (2012) 188:602735. doi: 10.4049 /jimmunol.1102639

188. Fitzhugh DJ, Naik S, Caughman SW, Hwang ST. Cutting edge: C-C chemokine receptor 6 is essential for arrest of a subset of memory $\mathrm{T}$ cells on activated dermal microvascular endothelial cells under physiologic flow conditions in vitro. J Immunol. (2000) 165:667781. doi: $10.4049 /$ jimmunol.165.12.6677

189. Clark RA, Chong B, Mirchandani N, Brinster NK, Yamanaka K, Dowgiert RK, et al. The vast majority of CLA $+\mathrm{T}$ cells are resident in normal skin. $J$ Immunol. (2006) 176:4431-9. doi: 10.4049/jimmunol.176.7.4431

190. Wang C, Kang SG, Lee J, Sun Z, Kim CH. The roles of CCR6 in migration of Th17 cells and regulation of effector T-cell balance in the gut. Mucosal Immunol. (2009) 2:173-83. doi: 10.1038/mi.2008.84

191. Cox KM, Commins SP, Capaldo BJ, Workman LJ, Platts-Mills TAE, Amir $\mathrm{ED}$, et al. An integrated framework using high-dimensional mass cytometry and fluorescent flow cytometry identifies discrete B cell subsets in patients with red meat allergy. Clin Exp Allergy. (2019) 49:615-25. doi: 10.1111/cea. 13322

192. Wirths S, Lanzavecchia $\mathrm{A}$. ABCB1 transporter discriminates human resting naive B cells from cycling transitional and memory B cells. Eur J Immunol. (2005) 35:3433-41. doi: 10.1002/eji.200535364

193. Wei C, Anolik J, Cappione A, Zheng B, Pugh-Bernard A, Brooks J, et al. A new population of cells lacking expression of CD27 represents a notable component of the B cell memory compartment in systemic lupus erythematosus. J Immunol. (2007) 178:6624-33. doi: 10.4049/jimmunol.178.10.6624

194. Ehrhardt GR, Hsu JT, Gartland L, Leu CM, Zhang S, Davis RS, et al. Expression of the immunoregulatory molecule FcRH4 defines a distinctive tissue-based population of memory B cells. J Exp Med. (2005) 202:78391. doi: $10.1084 /$ jem.20050879

195. Weiss GE, Crompton PD, Li S, Walsh LA, Moir S, Traore $\mathrm{B}$, et al. Atypical memory $\mathrm{B}$ cells are greatly expanded in individuals living in a malaria-endemic area. J Immunol. (2009) 183:2176-82. doi: 10.4049/jimmunol.0901297

196. Giesecke C, Frolich D, Reiter K, Mei HE, Wirries I, Kuhly $\mathrm{R}$, et al. Tissue distribution and dependence of responsiveness of human antigen-specific memory B cells. J Immunol. (2014) 192:3091-100. doi: 10.4049/jimmunol.1302783

197. Liu YJ, de Bouteiller O, Arpin C, Briere F, Galibert L, Ho S, et al. Normal human IgD+IgM- germinal center B cells can express up to 80 mutations 
in the variable region of their $\operatorname{IgD}$ transcripts. Immunity. (1996) 4:60313. doi: $10.1016 /$ S1074-7613(00)80486-0

198. Seifert M, Steimle-Grauer SA, Goossens T, Hansmann ML, Brauninger A, Kuppers R. A model for the development of human IgD-only B cells: genotypic analyses suggest their generation in superantigen driven immune responses. Mol Immunol. (2009) 46:630-9. doi: 10.1016/j.molimm.2008.07.032

199. Brestoff JR, Tesfazghi MT, Zaydman MA, Jackups R, Jr., Kim BS, et al. The $\mathrm{B}$ antigen protects against the development of red meat allergy. J Allergy Clin Immunol Pract. (2018) 6:1790-1. doi: 10.1016/j.jaip.2018. 02.010

200. Rispens T, Derksen NI, Commins SP, Platts-Mills TA, Aalberse RC. IgE production to alpha-gal is accompanied by elevated levels of specific IgG1 antibodies and low amounts of IgE to blood group B. PLoS ONE. (2013) 8:e55566. doi: 10.1371/journal.pone.0055566

201. Yan LM, Lau SPN, Poh CM, Chan VSF, Chan MCW, Peiris M, et al. Heterosubtypic protection induced by a live attenuated influenza virus vaccine expressing galactose-alpha-1,3-galactose epitopes in infected cells. mBio. (2020) 11:e0027-20. doi: 10.1128/mBio.00027-20

202. Wilson JM, Schuyler AJ, Schroeder N, Platts-Mills TA. Galactose-alpha-1,3galactose: atypical food allergen or model IgE hypersensitivity? Curr Allergy Asthma Rep. (2017) 17:8. doi: 10.1007/s11882-017-0672-7

Conflict of Interest: The authors declare that the research was conducted in the absence of any commercial or financial relationships that could be construed as a potential conflict of interest.

Copyright $\odot 2020$ Chandrasekhar, Cox and Erickson. This is an open-access article distributed under the terms of the Creative Commons Attribution License (CC BY). The use, distribution or reproduction in other forums is permitted, provided the original author(s) and the copyright owner(s) are credited and that the original publication in this journal is cited, in accordance with accepted academic practice. No use, distribution or reproduction is permitted which does not comply with these terms. 